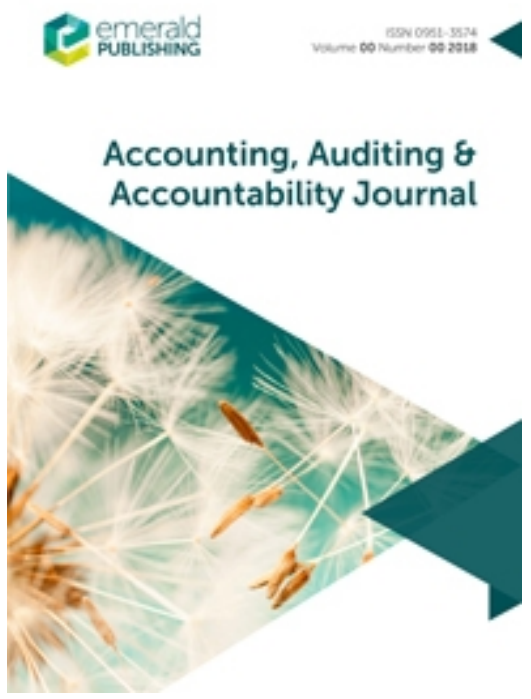

\title{
Examining the dynamics of SER evolution: An institutional understanding
}

\begin{tabular}{|r|l|}
\hline Journal: & Accounting, Auditing \& Accountability Journal \\
\hline Manuscript ID & AAAJ-07-2017-3044.R2 \\
\hline Manuscript Type: & Research Paper \\
\hline Keywords: & $\begin{array}{l}\text { Social and environmental reporting (SER), SER evolution-related } \\
\text { processes and conditions, Institutional Logics, Institutional } \\
\text { Entrepreneurship, Case Study, Italy }\end{array}$ \\
\hline \multicolumn{2}{|l}{} \\
\hline
\end{tabular}

\section{SCHOLARONE \\ Manuscripts}




\section{Examining the dynamics of SER evolution: An institutional understanding}

\section{Introduction}

Several studies have been conducted to investigate the motives, influencing factors and organisational effects of social and environmental accounting and reporting (hereafter SER) (see O'Dwyer, 2002; Adams and McNicholas, 2007; Dey, 2007; Bebbington et al., 2009; Fraser, 2012; Contrafatto and Burns, 2013; Belal and Owen, 2015). Despite the contribution provided by existing studies, theoretical understanding of the processes, dynamics and rationales behind the decision to initiate and implement SER into organisations is still largely "under-developed" (O'Dwyer and Unerman, 2016). As an attempt to address these criticisms, calls have been made for more in depth "theorized engagement" research (O'Dwyer and Unerman, 2016, p. 8) to provide well informed analysis of the processes through which SER intervenes, develops and (eventually) declines over time, with reference to contexts other than just profit-making listed companies (O'Dwyer and Unerman, 2016).

Consistent with these calls and augmenting research that more recently has examined SER initiation and/or decline (see Vinnari and Laine, 2013; Contrafatto, 2014a; Belal and Owen, 2015), this paper provides a theoretically informed analysis of the processual dynamics related to the evolution of SER within a case study organisation. For the purpose of this paper, the analysis of SER evolution involves the examination of 'how' (i.e. processes) and 'why' (i.e. the conditions under which) SER gradually emerged, was constructed and developed during the implementation and post-implementation phases. In particular, the empirical analysis has illuminated three stages in the evolution of SER, namely: i) the 'birth' whereby a new form of social reporting emerged; ii) the 'development' through which SER was implemented to become part of the managerial mechanisms for "mission re-balancing" and for "re-constructing" trustworthy relationships with the main stakeholders; and iii) the 'de-structuring' when SER was gradually de-composed to become a symbolic element of corporate communication.

The paper is based on a fieldwork case study conducted from 2011 to 2015 with a cooperative bank in Italy. Information and data were collected through several methods including: interviews with managers; analysis of SER-related documents; analysis of the website; and observations during the visits. The analysis of the empirical evidence draws on the so-called Institutional Logic Perspective (Thornton et al., 2012; Thornton and Ocasio, 2008; Thornton, 2004), which provides valuable theoretical insights to interpret the role of the contrasting institutional forces and logics in the evolution of organisational practices such as accounting.

This paper offers three main contributions to the existing (social accounting) literature. First, the analysis provides evidence of the conditions related to the evolution of SER by illuminating not only the implementation but also the post-implementation dynamics. Second, the paper shows that SER is multifunctional in nature and unveils how and why these multiple functions change over time depending on the specific institutional and organisational conditions. Finally, this paper provides a theoretical contribution by adding empirical evidence to understand the mechanisms of institutional change and the role that different (and contrasting) institutional logics play in driving organisations to adopt specific management and (social) accounting practices.

The paper is organized as follows. In the next section, a brief review of the existing studies, which have examined the dynamics of SER implementation, is provided. Section 3 discusses and develops the theoretical framework adopted in this paper with particular reference to the notions of institutional orders, logics and institutional entrepreneurship. In section 4, we present the research methodology and method. In sections 5 and 6 , we discuss the context of the case study and present our empirical analysis. Finally, conclusions are reported. 


\section{SER and the dynamics of implementation}

Many studies have been conducted to investigate, through for example engagement-based approaches, the different facets of decision-making related to social and environmental accounting, including the factors influencing SER; the effects of SER in different organisational domains; and the motives for accounting and reporting.

These works have provided significant theoretical and empirical contributions to advance the understanding of some of the complexities related to SER decision-making (O'Dwyer and Unerman, 2016). In particular, existing literature (e.g. Larrinaga-González and Bebbington, 2001; Dey, 2007; Fraser, 2012; Contrafatto and Burns, 2013) has unveiled inconsistency and apparent contradictory results about whether SER interventions produce change towards less unsustainable forms of organizing. As observed by Contrafatto (2014a), these contrasting results may be explained by considering the different institutional, contextual and organizational conditions and factors (e.g. country, industry, type of organisations) that characterize these studies. These multifarious factors also affect the nature and quality of SER practices (Adams and McNicholas, 2007; Bebbington et al., 2009) as well as the decision-making about SER's initiation and implementation. The decision to adopt, implement and sustain SER practices in organisations, thus appears to be influenced by several institutional, contextual and organisational factors as well as by some complex managerial motives to use these practices strategically for managing environmental and reputational risks (Georgakopoulos and Thomson, 2008) and for acquiring legitimacy (Deegan, 2002; O'Dwyer, 2002). Most of the existing research on motives has provided evidence for some kind of legitimacy-related explanations for the voluntary adoption and implementation of SER (e.g. Deegan, 2002; O’Dwyer, 2002; Tilling and Tilt, 2010; Belal and Owen, 2015). This research has mostly sought to investigate the strategic, instrumental or symbolic motives for SER rather than its drivers, logics of actions and cascading effects. Overall, these works have predominantly focused on the 'managerial motives' and 'factors' that are relevant for the decision-making related to the initiation and implementation of SER, as well as its nature and role within organisations. This research would need to be supplemented by studying in more depth, as argued by O'Dwyer and Unerman (2016), "how this [accounting and] reporting is constructed and used in a wide variety of organisational contexts" (p. 7, emphasis added). It is through an understanding of the "how-related processes' of SER construction and evolution, as well as of the 'conditions under which these processes occur' (i.e. the why-question), that it is possible to grasp a fuller understanding of the potential and/or actual role of SER for promoting change towards less unstainable business and organisational practices (Contrafatto, 2014a).

In the existing literature, there is a relative dearth of research which has examined SER-related processes and, in particular the dynamics, logics and conditions of SER evolution. The majority of the existing studies which have adopted some form of engagement-based approaches to investigate the process of SER construction have mainly focused on the factors and conditions influencing this process (Bebbington et al., 2009), on the difficulties and politics involved (O'Dwyer, 2002; Fraser, 2012) and on the initial implementation stages (Adams and McNicholas, 2007; Contrafatto et al., 2015). Only a few studies (see e.g. Vinnari and Laine, 2013; Contrafatto, 2014a; Belal and Owen, 2015) have particularly examined SER's development by considering not only the initial construction but also the evolution over time.

For example, Vinnari and Laine (2013) examined the introduction, diffusion and gradual decline of environmental reporting in the water sector in Finland. Their analysis, which focuses on a multicase study of five (public) utilities, showed that the initial diffusion was explained from the perspectives of fad and fashion, whereas the subsequent decline of such reporting was driven mainly by internal organizational factors (e.g. disconnection from the management control systems) and lack of outside pressure, such as the absence of public demands for wider transparency or corporate social responsibility. Similarly, Belal and Owen (2015) analyzed the "drivers" (p. 1181) for the development and subsequent discontinuation of SER in a multinational subsidiary of a tobacco company in Bangladesh. Their analysis suggested that SER was initially introduced to 
legitimize the subsidiary's activities in a specific context (i.e. Bangladesh) where both tobacco control regulation and anti-tobacco movements were gaining momentum. However, SER was subsequently dismissed in the face of a complex combination of global and local factors, such as the shifts in the national policy concerning tobacco control and the increasing criticisms of local and international NGOs. Although Vinnari and Laine (2013) and Belal and Owen (2015) do not specifically provide an in-depth analysis of 'how' (i.e. the processes and dynamics) SER evolved over time, their work is significant for two reasons. First, their papers provide insights to understand the forces and factors that are involved in the diffusion and decline of SER over time. Second, their analysis highlights the relevance that context-related conditions (e.g. country, industry, type of organisations) may have for decision-making about SER, in particular in contexts other than forprofit listed organisations (see in particular Vinnari and Laine, 2013), where the need to provide information to the stakeholders arguably transcends financial aspects (Larrinaga-Gonzáles and Perez-Chamorro, 2008).

Similar considerations about the importance of focusing on different contexts other than forprofit listed organizations are reported by Contrafatto (2014a). Contrafatto (2014a), who examined the processes through which SER, after its first implementation, developed and became an institutionalized practice, suggests that such organisations provide useful settings to unveil some of the complexities related to the interweaves between SER decision-making and institutional conditions $^{1}$. For example, in nonprofit organisations (Dees, 1998) and hybrid organisations (Ebrahim et al., 2014), the mission is not generally driven by the sole economic/market logics aimed at profit-seeking, but also by the society/community-related logics (Ebrahim, 2009). These organisations, in which different and contrasting institutions and logics may co-exist (e.g. community logic versus market logic), provide alternative loci of analysis for investigating the emergence of organisational practices, including SER, in complex institutional environments. The analysis of nonprofit and/or hybrid organisations, for example the cooperatives, helps to gather a wider understanding of the processes and conditions of construction and evolution of (social) accounting and reporting (Busco et al., 2017) in contexts other than conventional corporations (O’Dwyer and Unerman, 2016).

This paper focuses on the evolution of SER. In particular, the paper examines 'how' and 'why' this evolution occurred by investigating the processes and institutional conditions through which SER was firstly introduced and implemented and gradually de-structured in a case study. This analysis was undertaken in an Italian cooperative bank, whose managerial decisions were influenced by powerful conflicting institutional logics.

\section{The Institutional Logics Perspective: A theoretical framework for exploring SER evolution}

In this paper insights from the so-called Institutional Logics Perspective (Thornton et al., 2012; Thornton and Ocasio, 2008; Thornton, 2004; Ocasio et al., 2017) are adopted to provide a theoretical framework for analysing the processes of SER evolution in the case study. This perspective, which emphasizes the relevance of the Institutional Logics, is adopted because it helps to examine "how" and "why" individual and organizational actions and practices, such as for example the social accounting-related practices, are affected by the multiple institutional logics of a specific institutional context. Moreover, this perspective is also suitable for exploring the dynamics through which individuals, through their agency (Seo and Creed, 2002; Battilana et al., 2009), are able to challenge, modify and innovate existing institutions and institutional logics (Damayanthi and Gooneratne, 2017). Thornton et al., (2012) emphasize that individual and organizational behaviour is always embedded in (Holm, 1995; Seo and Creed, 2002), and thus influenced by, the

\footnotetext{
${ }^{1}$ The analysis of Contrafatto (2014a) is relevant to this paper because it emphasizes the importance of the institutional-related factors and dynamics for understanding the decision-making about SER.
} 
specific institutional context, which "both regularizes behaviour and provides opportunities for agency and change" (pp. 101-102). The following sub-section briefly discusses the core notion of the Institutional Logics Perspective.

\subsection{Institutional logics: elements, factors and effects}

The notion of institutional logics (ILs) has been extensively used in the organization, management and accounting literatures. In particular, ILs-inspired research has been conducted in several fields across disciplines, such as, health care organizations (Scott et al., 2000); book publishing companies (Thornton, 2004); microfinance (Battilana and Dorado, 2010); and accounting-focused research (Ezzamel et al., 2012; Boitier and Riviere, 2013; Lander et al., 2013; Busco et al., 2017. For a review see Damayanthi and Gooneratne, 2017). Although the phrase 'institutional logics' has been widely used, the concept is still "arguably difficult to define and even harder to apply in an analytically useful manner" (Thornton et al., 2012, p. 1). In this sub-section, drawing on the works of Thornton et al., (2012) and Thornton and Ocasio (2008), we provide a definition of ILs and we conceptualize their nature, elements and effects. Thornton and Ocasio (2008) define ILs as the

"socially constructed, historical patterns of cultural symbols and material practices, including assumptions, values and beliefs by which individuals and organizations provide meanings to their daily activities, organize time and space and reproduce their lives and experiences" ( $p$. 101).

First, this definition, which highlights the "substantive"2 (Quattrone, 2015, p. 436) nature of the logics, emphasizes that ILs represent "socially constructed" and "historically-bounded" patterns, i.e. they emerge, develop and are affected by the actions of interested actors in specific historical and social conditions. Second, ILs are composed of several categorical elements, which include cultural-symbolic elements (e.g. values, symbols) and material aspects (e.g. practices and structures) of the institutions. Ocasio et al., (2017) explain that the cultural-symbolic and material elements represent the essential components of each institution ${ }^{3}$. Third, with regard to the effects, ILs provide the (institutional) resources (e.g. the cultural-cognitive frameworks and vocabularies) for understanding and attaining social and economic phenomena. ILs play an essential role in guiding what individuals (can) do, by providing them "with means-ends designations [and] organizing principles" (Pache and Santos, 2010, p. 457) to assess the range of activities that are considered appropriate and attainable. In summary, ILs constrain/shape the cognition, interests and behaviour of organizational actors, but also provide the resources, opportunities and impetus for agency and change.

In the following sub-section, the model proposed by Thornton et al., (2012) is discussed with the aim of highlighting the theoretical framework used to guide the empirical analysis. We draw on this model to unveil the several institutions and related logics which were relevant for explaining the evolution of SER in our case study. In particular, the multiple ILs that we observed posed alternative and contradictory institutional demands for the organizational actors. These contradictions, we argue, created the space and provided the resources and opportunity for innovating the SER-related practices ${ }^{4}$.

\footnotetext{
${ }^{2}$ Quattrone (2015) challenges the substantive view by proposing that ILs have rather a procedural nature. It is this procedural nature that helps to explain institutional dynamism.

${ }^{3}$ Thornton et al., (2012, p. 10) emphasize that the cultural-symbolic elements denote the most intangible components of institutions (e.g. meaning systems, beliefs, values), whereas the material aspects represent "the practices and structures" (e.g. activities, rules, routines).

${ }^{4}$ In our paper, in contrast to other ILs-infused research in accounting (see Busco et al., 2017; Boitier and Riviere, 2013), we propose an enriched theoretical framework that combines the theory of the multiplicity and pluralism of ILs with the theory of institutional entrepreneurship. In so doing, our framework helps to investigate in more depth the conditions and processes through which institutional and organizational change occurs. For a review of studies which have integrated the ILs framework with other theories (e.g. structuration theory) see Damayanthi and Gooneratne (2017).
} 


\subsection{The foundations of the Institutional Logics Perspective: An interpretive framework}

Thornton et al., (2012) propose a model to illustrate the "[t]heoretical architecture" (p.50) of the Institutional Logics Perspective and the building components of the several institutions and related logics. The model is conceptualized as a two-dimensional matrix (X-axis and Y-axis) $)^{5}$, which includes, on the $\mathrm{X}$-axis the several institutional orders, and, on the Y-axis, their categorical elements. The cross-combination between the categorical elements ( $\mathrm{Y}$-axis) of each institutional order (X-axis) highlights the cell contents (X, Y), which provide detailed examples of the cultural symbols or material practices that characterize a specific institution (see Table 1).

\section{[Table 1 here]}

The concept of inter-institutional system is used to represent the several institutions of society. According to Thornton et al., (2012), society can be understood as a system of near-decomposable and partially autonomous institutions. These institutions are depicted as sub-systems, which, though distinguishable and autonomous, are interrelated to form the inter-institutional system of a specific social and historical time. Each sub-system, thus, represents a different set of expectations for social and institutional relations. Thornton et al., (2012) call these sub-systems institutional orders. Institutional orders, which are represented on the X-axis, denote a distinguishable "domain of institutions $[\ldots]$ that represents the cultural symbols and material practices that govern a recognized area of [institutional] life. [An] institutional order represents a governance system that preconditions actor's sense making and choices" (p. 54).

As emphasized by Thornton and Ocasio (2008), each order is characterized by specific institutional logics. Examples of institutional orders are: family, religion, state, market, corporation, profession and community ${ }^{6}$. Each order is characterised by a specific form of institutional rationality and logics, which influence and condition cognition, interests and actions. Hence, from an Institutional Logics Perspective multiple rationalities exist as many as there are institutions. The existence of this multiplicity of institutions and related logics may generate conflicting and contradictory institutional influences. For instance, as emphasized by Pache and Santos (2013) and Busco et al., (2017), this is the situation which may characterize hybrid organizations such as microfinance institutions (Battilana and Dorado, 2010), research and development firms (Busco et al., 2017) and cooperatives. These organisations are characterized by a "dual" nature and mission, both financial/economic and social/ethical, whose accomplishment may generate conflict and tension (Dees, 1998). In the cooperatives, for example, the tensions between social- and economicoriented logics may produce a drift (Ebrahim et al., 2014; Mersland and Strøm, 2010), i.e. a disequilibrium in the status quo and a deviation from the original purpose and mission of the organisation.

In addition, each order is conceptualized as composed of several "elemental categories" (Y-axis, Table 1), which refer to the cultural symbols and material practices/structures related to that order. The elemental categories represent the building blocks of the ILs, i.e. the key elements that specify the organizing principles that shape individual and organizational preferences, interests and behaviours. Thornton et al., (2012) provide an illustrative example of these categories: root metaphor, sources of legitimacy, sources of authority, sources of identity, basis of norms, basis of attention, basis of strategy, control mechanisms and economic systems.

In this paper, the matrix proposed by Thornton et al., (2012) has been modified to include under the 'Basis of control' category, 'Accountability forms' which, along with 'Control Mechanisms',

\footnotetext{
${ }^{5}$ Thornton et al., (2012) adopt the $\mathrm{X}$ and $\mathrm{Y}$ terminology to describe the matrix and to provide a graphical representation, rather than a definitive classification, of the components of the inter-institutional system.

${ }^{6}$ Thornton et al., (2012) emphasise that the list of institutional orders is meant to be illustrative and be used as a guide for conducting empirical research. It is plausible that other institutional orders, or hybrid forms of these, may emerge in specific empirical settings.
} 
describe and characterize the elements of control related to each institutional order (see Table 1). The purpose of this inclusion is to illustrate the several forms and mechanisms of accountability (that have been elaborated in the accountability literature), which might characterize each institutional order. We contend that this inclusion helps to enrich the model proposed by Thornton et al., (2012), by exemplifying the forms of accountability which reflect, and may be characterised by, a specific institutional order. For instance, the institutional order of 'Community' could be characterized by forms of 'public interest accountability', which are typical of nonprofit organisations (Ebrahim, 2009). In this context, accountability mechanisms may be less formal and hierarchical (O'Dwyer and Unerman 2008), than is commonly expected in corporations. For example, a community-based organisation, in reporting actions/initiatives to their members or communities, may adopt accountability mechanisms which are less technical and more informal than is usual in the context of financial or corporate accountability. On the other hand, the institutional order of 'Religion', whose control mechanisms are based on devotion and worship, could be characterized by stewardship-infused forms of accountability, whereby the actions of a steward are grounded and driven by "principles of spirituality" (Contrafatto, 2014b, p. 184).

To synthesize, the model proposed by Thornton et al., (2012) highlights the existence of multiple, near-decomposable and partially autonomous institutional orders, which are composed of specific categorical elements and characterised by specific ILs. Existing ILs establish core values and guiding principles for regulating activities and channelling interests. In other words, the interests, actions and behaviours of organizational actors are directed and regulated by the specific institutional context in which they are embedded.

The term "embedded agency" (Holm, 1995; Seo and Creed, 2002) is used in institutional analysis to denote that individuals' agency should be understood as always institutionally "situated" (Battilana et al., 2009), that is immersed, conditioned and limited by the existing institutions and related ILs. On the other hand, institutions and related ILs also provide individuals and organizations with the resources, opportunities and impetus for institutional change. This tension between "institutional embeddedness" and "human agency" has been termed the "paradox of embedded agency" (Holm, 1995; Seo and Creed, 2002). Seo and Creed (2002) explain this paradox through a question: how and under what conditions could agents mobilize resources to transform their institutional arrangements when their "[means], actions, intentions and rationalities are conditioned" (p. 223) by the existing institutional conditions?

Working on this tension, institutional scholars (e.g. Greenwood et al., 2002; Seo and Creed, 2002; Battilana et al., 2009) have investigated the conditions and processes by which institutional change occurs. With regard to this, the Institutional Logics Perspective provides valuable insights to explain these institutional change-related issues (Damayanthi and Gooneratne, 2017). In particular, the multiplicity of institutional orders and related logics, which may exist in a specific situational context, has the potential to create contradictory institutional influences on individuals and organizations (Pache and Santos, 2010; 2013). According to Thornton et al., (2012), these contradictions and fragmentations between differentiated ILs, create the space and provide opportunities for institutional change. As emphasized by Seo and Creed (2002), the processes of institutional change are conceptualised as the "dynamic relationship[s] among institutional embeddedness, contradictions" and human agency (p. 230). Thus, institutional contradictions are fundamental enabling factors for innovation and institutional change. However, Seo and Creed (2002) explain that these contradictions per se do not lead "deterministically" and "automatically" to such changes. The differentiation, contradictions and fragmentations of institutions and ILs provide opportunities and are "specifiable probabilities rather than inevitabilities" (p. 229) for change. With regard to this, a pivotal role is played by "human agency" 7, which represents the activating mechanism for transforming these opportunities into actual change (Seo and Creed,

\footnotetext{
${ }^{7}$ Drawing on Scott (2008), the concept of agency denotes the "actor's ability to have some effect on the social worldaltering the rules, the relational ties, or distribution of resources" (p.77).
} 
2002). Institutional agency may be exerted through different forms, such as, for example, institutional entrepreneurship.

The concept of institutional entrepreneurship (DiMaggio, 1988, Hardy and Maguire, 2008, Battilana et al., 2009) is used to describe the ability of innovative individuals or collective actors (e.g. pro-active managers) to change existing institutions. These "innovative" individual/collective actors represent the "institutional entrepreneurs" (DiMaggio, 1988), i.e. the agents who are able to mobilize resources (e.g. knowledge and charisma) to exert some form of agency for challenging, transforming and disrupting institutions and institutional arrangements. Battilana et al., (2009) emphasize that institutional entrepreneurs represent a "specific" type of change agents, who accomplish two main tasks: i) to initiate divergent change projects that break with existing institutional and organisational arrangements; ii) to actively partake in the implementation of these projects through different activities. The initiation of these change projects may be done intentionally or unintentionally. In addition, the initiation and implementation of these projects should not necessarily lead to successful forms of change.

The possibilities for institutional entrepreneurship are enhanced by several enabling factors and conditions. Battilana et al., (2009) classify these factors/conditions into: i) field-level factors, which are related to the macro institutional context; ii) organisational-related factors, which refer to the organizational structure; iii) actors' social position in the field and/or organisation; iv) individualrelated factors, such as the individuals' attitudes and socio-demographic background. For instance, as explained by Thornton et al., (2012), entrepreneurial behaviours occur at increased rates in specific conditions, such as: technological disruption and/or innovation; economic crisis and social upheaval; occurrence of salient events (e.g. ecological disasters, un-ethical cases); change in management attitudes; the adoption of managerial innovations (e.g. specific control systems) and the specialisation and inter-organisational mobility of individuals. All these institutional/organisational/individual conditions provide the necessary resources (e.g. knowledge, aptitude and authority) to identify and implement initiatives to cope with, challenge and innovate existing institutions. Different strategies can be adopted for exerting institutional entrepreneurship. For instance, organizational actors could adopt initiatives which segregate, transpose and/or blend existing institutions and ILs. Thornton et al., (2012) explain that segregating describes the process whereby elements of a specific institutional order (e.g. symbols and material practices) are strategically excluded from the analysis. Transposition refers to the situation when categorical elements of an institutional order migrate to, or are transferred to, a substantively different context. Finally, blending is the process whereby elements of different institutional orders are combined and blended together to create something new in terms of institutional practices and ILs.

\section{Methodology and Methods}

The paper is based on a qualitative fieldwork case study (Creswell, 1998; Ahrens and Chapman, 2006; Silverman, 2011), with empirical work in the field carried out from September 2011 to July 2015, with an Italian cooperative bank. The study is also supplemented by an archival analysis of the SER-related documents published from 1999 to 2015. The theoretical insights discussed above are used to frame the analysis of the empirical findings and to provide a theoretically-grounded explanation of the processes and conditions through which SER evolved over time in the case study. The choice of focusing on a single case study was made because it allowed more in-depth examination of the SER-related processual dynamics and the context within which these occurred (Eisenhardt, 1989). In addition, the choice of studying a hybrid organisation (i.e. a cooperative) was made because these organisations, which are subjected to the influences of multiple institutional logics, provide a rich context of analysis for illuminating some of the complexities related to SER decision-making processes. Finally, the specific case study organization was selected because of its long-standing involvement and experience in SER-related practices. From this perspective, our study represents a "theoretically useful case" Eisenhardt (1989, p. 533) which offers insights for 
extending theoretical understanding of (social) accounting intervention within organisations (Ahrens and Chapman, 2006).

Empirical data was gathered through several research methods including: 14 semi-structured interviews, along with informal talks, with managers; analysis of SER-related documents; and observations in the field. The personnel interviewed took part, to differing degrees of participation, in the SER-related processes as organizers, drafters or data-collectors. These included several managers, such as for example the CEO, President, Deputy CEO, who were directly involved in the adoption and/or implementation of SER. All the interviews were tape-recorded, fully transcribed and analyzed. The duration of each interview varied from a minimum of 45 to a maximum of 90 minutes. Overall a total of 14 hours of interviews were conducted, with approximately 240 pages of transcripts generated (see Table 2 for more detail).

\section{[Table 2 here]}

All data and transcripts were systematically analysed following a coding protocol analysis, which involved three sub-processes: data reduction; data display and data interpretation. These three sub-processes were preceded by a preliminary analysis that was undertaken during the transcription of the taped-interviews. This preliminary analysis helped to gather an overall understanding of the collected data. This was followed by an iterative process of data reduction, through which codes were generated, categorized and reduced. This process, which was supported by using Atlas.Ti software, led to the identification of the main 'core codes' (O'Dwyer, 2004) for each of the themes identified through the analysis (Table 3 provides a synthetic description of the processes of codes generation and reduction).

[Table 3 here]

The entire process of coding generation/reduction was characterized by constant interactions between the researchers involved in the project. These interactions helped to enhance the completeness and consistency of the core codes identified.

The process of data reduction was then followed by the processes of data display and data interpretation. Matrices, memos and conceptual maps were used to display the information gathered during the investigation and to support the process of interpretation of the empirical findings (see O'Dwyer, 2004). Furthermore, the coding process helped us to engage with the interview materials and to develop a deeper understanding of the information collected during the analysis. Finally, after revisiting the field notes, memos, summary matrix and content analysis results, the interpretation was possible.

In addition, a content analysis of the social and environmental reports published from 1999 to 2015 by the bank was carried out (Krippendorff, 2004) to supplement the fieldwork findings. The content analysis included two different phases. The first one, which is more descriptive (e.g. number of pages and issues covered), was performed with an explorative intent to gain familiarity with the content of the social and environmental reports (see Appendix 1). In conducting the content analysis, the number of pages was adopted as the unit of measurement to analyze the narrative disclosures (Unerman, 2000). In addition, the visuals in the reports were also analyzed (Pesci and Costa, 2014).

The second phase of the content analysis was more thematic, i.e. it draws from, and focuses on, the different logics identified in the adopted theoretical framework and complements the overall empirical investigation. In particular, Table 1 was used as a grid to aid the thematic-focused analysis (O'Dwyer, 2004). In both phases of the content analysis, all the researchers sought consistency of the data by continuous interactions and discussions directed to resolving discrepancies in the codification process. Finally, all the researchers participated in the content analysis in order to enhance the reliability of the results. 


\section{The institutional and organisational context of the empirical analysis}

The case study examined is a cooperative bank located in Trentino, a region in Northern Italy. Cooperative banks (hereafter $\mathrm{CBs}$ ) represent a specific form of hybrid organizations which are owned by their members, under the principle "one person, one vote" 8 . As explained by Fiordelisi (2014), CBs are inspired by several social-infused principles such as solidarity, fighting against exclusion and social and environmental responsibility, which represent their core values and the source of their mission and actions (Leonardi, 1982; 1998).

In the remainder of this section, we analyze the institutional and organisational context which influenced the dynamics of emergence and evolution of SER in our case study. We start by describing the historical and socio-economic conditions that characterize Trentino to explain how CBs evolved and how they operate. Then we proceed by providing a brief description of the case study organization. This analysis helps to understand how the bank, and related SER processes, developed as they did.

In the past, living conditions in Trentino were particularly difficult due to geographical features of the territory, which is mainly characterized by mountains and valleys. Cooperation in this context was seen, as emphasized by Interviewee 13, as a "powerful weapon" for mitigating the hardship of this impervious territory, where villages and communities were scattered in isolated and poorly connected valleys. These hard geographical features had a strong impact on the way in which people conducted and organized their life because they helped to create a strong feeling of being part of a common destiny (Leonardi, 1982). As put by Interviewee 10, "hardship and struggles for survival pushed a common vision for everybody to look in the same direction". In other words, in this specific context a sense of community emerged, i.e. a sense of being subjected to, and part of, common conditions and exigencies to share with others. This feeling of belonging and being part of a community with a specific culture and habits connected to a specific territory, enhanced the diffusion and sharing of common values and principles, which still permeate the local life and economy.

Historically, the first forms of CBs in Trentino emerged at the end of the $19^{\text {th }}$ century (Leonardi, 1982). This period was mainly characterized by agriculture-based forms of economy and localized handicraft. In particular, the term "Rural Banks" was originally coined to describe these forms of CBs. The etymology of the term "Rural", which refers to countryside, recalls the primary role that these banks at that time played in supporting the economic and social needs of the rural local communities (i.e. farmers, artisans and families). As emphasized by Interviewee 4, the rural bank was "a model which emerged to assist people living in Trentino's valleys [...]. The fundamental idea behind cooperation was to create a network of aid to ensure that people could enhance their life conditions". This analysis shows that Trentino's socio-economic life has been particularly influenced by, and centered on, communities, which have provided individuals with resources for their self-identity and actions. From the perspective of the theory adopted in this paper (Thornton el al., 2012), therefore, community has always represented a relevant institutional order which has driven the life of Trentinian communities.

In the emergence of the first CBs in Trentino, a significant role was played by a Catholic priest, Don Guetti, who is widely considered the 'spiritual founder' of these banks (Leonardi, 1982). Leonardi (1982) explains that Don Guetti helped to infuse the Catholic-based principles of 'centrality of person' and 'solidarity' into the core values of these first banks. According to

\footnotetext{
${ }^{8}$ It is important to note that CBs in Italy are not allowed by law to distribute their profits, which are re-invested in the organization or, under certain conditions, given as benefits to members.

9 The governance model of CBs includes two main bodies, the General Assembly, which represents the members' needs/expectations, and the Board of Directors. The Board of Directors, which is elected by the General Assembly, is responsible for the key management decisions, including the production of the financial statements. A prominent role is played also by the President who reports to the Board of Directors (Leonardi, 1998).
} 
Interviewee 10, centrality of person and solidarity meant to live and work "closely especially with/to those people who are in hardship, who alone could not ensure their basic human needs". From our analysis, it appears that an indissoluble link between the difficult conditions of Trentino (i.e. geographical, socio-economic) and Catholic religious values exists (Leonardi, 1982). As emphasized by Interviewee 13,

"The fact that the original idea of cooperation started with a priest has definite relevance, because people in Trentino surely had this strong faith and belief in these [Catholic] principles which sustained their difficult life".

From the institutional logic perspective, these principles/values reflect the logics of a religion-based institutional order (Thornton and Ocasio, 2008). In particular, our analysis reveals that these two intertwined institutional orders and related logic (i.e. community-related and religious inspired) played a fundamental role in the origins, emergence and evolution of Rural Banks in Trentino.

Nowadays, Trentino is one of the richest regions in Italy ${ }^{10}$. Hence, in this specific context, which is characterized by economic wealth, the high concentration of banks is not surprising (Bonfanti, 2009). Furthermore, the same geographical features (i.e. mountains, valleys), which in the past represented an impediment to survival and quality of life, now, in a situation of relative economic wealth, provide, in the words of Interviewee 5, a "sort of natural custom protection". From this perspective mountains and valleys represent also a barrier against potential new competitors and, in doing so, they help to protect the economy of the region but also to preserve the habits, customs and traditions of local communities.

Since the mid-1990s the development of the CBs in Italy, and in Trentino in particular, has been influenced by several factors and events that occurred in the wider social and institutional context. These factors and events played an important role in understanding how and why CBs evolved as they did from the end of the $20^{\text {th }}$ century. In particular, some disruptive events and crises (e.g. the crisis of Argentinian bonds in the early 2000s; the 2008 "Credit Crunch") have profoundly impacted on the overall banking sector, by affecting the trustworthiness and credibility of the entire system. These crises represented relevant "institutional sequencing events" (Thornton et al., 2012) which challenged the existing stability and triggered institutional changes in the regulation and management of the entire banking sector. These events and related changes also impacted on the $\mathrm{CBs}$, including the bank in our case study. The sense of economic crisis, financial instability and lack of trust in business conduct spurred CBs to reconsider the conduct of their activities (Almandoz, 2012). As a result, several initiatives were undertaken to manage and organize the activities of the CBs. For instance, a new motto, "my bank is different", was proposed by the CBs' Italian Union. This motto was used as a strategic communication tool to differentiate the CBs from others and to dissociate themselves from the commercial banks. In this context of economic and financial crisis, the original founding CBs' values of 'cooperation' and 'community involvement' gained new impetus. According to Interviewee 3,

"our model has cushioned better against the consequences of the crises... [...]. We are proud to be a cooperative bank [...]. [The Central Bank Governor] has said that without the CBs the impacts of the crisis on [our] communities would have been much stronger".

From our analysis, it emerges that during the years of the financial/economic crises, the CBs in general (see, for example, the initiative of the CBs' Union), and the examined bank in particular, put more emphasis on their differentiating features by highlighting their cooperative-inspired principles and community-oriented values. Based on these principles, many community-investment initiatives (e.g. philanthropic activities, sponsorship) were, and are still, undertaken by CBs. As

\footnotetext{
${ }^{10}$ See I.Stat statistics at: http://dati.istat.it/Index.aspx?DataSetCode=DCCN_VALPROCAPT (accessed on May 2017).
} 
explained by Interviewee 9, all these initiatives represent "part of our DNA". We observed that these activities and initiatives create a sense of belonging in the community and produce a strong cohesion among people who participate in the life of the case study bank (hereafter the Bank).

The Bank was founded at the end of the $19^{\text {th }}$ century. Later the name "Rural Bank" was adopted to highlight the critical role that it played in bolstering the local rural economy by supporting the efforts of post-war reconstruction. In addition, the city in which the Bank is located has historically represented an influential centre for the development of industries which have been important for the whole regional economy. This specific location has given the Bank the opportunity to compete with other banks and in particular with commercial ones, adopting similar strategies and offering similar products. The Bank, which employs more than 100 people, has always played an important role in the economic development of the region.

\section{The emergence, implementation and de-structuring of SER}

In this section, we present the empirical analysis of the institutional logics-influenced dynamics of SER evolution in our case study. Figure 1 illustrates the 'timeline of the story' and highlights the processes and (institutional logics) conditions whereby SER was initiated, implemented and gradually de-structured. From our empirical analysis, three main phases have been identified: i) the 'birth' whereby a new form of SER emerged; ii) the development through which the SER was implemented and structured; iii) the 'de-structuring' ${ }^{11}$. These three phases are discussed in the following sub-sections.

\section{[Figure 1 here]}

\subsection{The birth of SER: the emergence of a new practice}

In the examined Bank, SER emerged at the end of the 1990s when the first Social Report (i.e. Bilancio Sociale) was published in 1999. The first Bilancio Sociale was a basic form of social accounting and reporting; it was 33.5 pages long and included only limited information about social and environmental aspects related to the (mainly philanthropic) activities of the Bank (see Appendix 1). As stated by the CEO in the letter of introduction, the aim of the first Bilancio Sociale was to "make the stakeholders and the whole community aware of the role played by the Bank in its local context" (Bilancio Sociale, 1999, p.4). As emphasized by Interviewee 13, the first Bilancio Sociale was a "really small booklet" prepared by "putting together, in roughly two months, small pieces of available information" about the social activities of the Bank. The first Bilancio Sociale, therefore, seemed to be the outcome of the 'cut and paste' of existing information that was drafted in a hurry on the basis, in the words of an interviewee, of "home-made techniques to provide a very simple story about [our] Bank and its activities" (Interviewee 5).

The first Bilancio Sociale included, as it emerges from our content analysis, photos that represented the faces of the employees, members and customers of the several Bank branches. In terms of content three main topics were disclosed: mission/values; organizational structure and governance; and philanthropic donations. Although the first Bilancio Sociale was a basic and limited social account and report, its predisposition represented a landmark in, and springboard for, the development of SER. The first Bilancio Sociale was, even with all its limitations, a very important document because, as contended by Interviewee 5, "it encouraged us to think and make a step forward to improve our existing practices". Before discussing the development of the SER practices over time, it is important to ascertain 'how' and 'under what (institutional) conditions' the first Bilancio Sociale emerged.

\footnotetext{
${ }^{11}$ At the outset, it should be clarified that 'de-structuring' is used to denote changes (e.g. in terms of content, format, policies) that affect the manifestations of the reporting processes and report. These changes are discussed in more detail in sub-section 6.3
} 
From the analysis of the empirical findings it appears that, the first Bilancio Sociale emerged out of the initiative of the previous CEO (see the Introduction to the Bilancio Sociale 1999). As emphasized by the interviewees who experienced this process, the first Bilancio Sociale was the result of the decision made by the previous CEO who, together with the Deputy CEO, "prepared and wrote the whole of this [report] by giving a somewhat realistic snapshot of the world of our Bank at that time" (Interviewee 5). These individuals, thus, acted as the fathers of the first Bilancio Sociale, who were able to initiate a new process and to introduce a novel organisational tool. To some extent, it appears that they performed some form of institutional entrepreneurship (Di Maggio, 1988) because they were able to mobilise organizational resources (e.g. their charisma and role in the organisation) for challenging the organizational status quo and for proposing innovation in the existing forms of communication with stakeholders. In addition, as emphasized by Interviewee 2, the first Bilancio Sociale was prepared on the occasion of the Bank's centenary; it was proposed as a novel initiative, among others, to celebrate the anniversary. As also specified in the Introduction to the 1999 Bilancio Sociale, the document was a "specific celebratory document" that was prepared to "make visible to the local communities the multiple activities of the Bank" (Bilancio Sociale 1999, pp. 4-12). From the perspective of the theory adopted in this paper, the centenary represented a "salient endogenous event" that triggered some form of "institutional entrepreneurship" (Battilana et al., 2009) through which to propose innovation in the managerial procedures of the organization. In this sense, the first Bilancio Sociale was a creation by the CEO and Deputy CEO who modelled this document into a fashionable managerial tool. As emphasized by the employees who were involved in these processes, the first Bilancio Sociale was created almost "for fun and for play" (Interviewee 13) and "following the fashion that considered a Bilancio Sociale something cool" (Interviewee 4). From this perspective, therefore, the Bilancio Sociale resembled a special celebratory gift for the Centenary to be used as a form of managerial toy,

"I don't think that there was at the time a real conviction in taking forward and advancing this project. In this sense, this project was born almost by an accidental situation" (Interviewee 8).

In summary, our analysis indicates that the first Bilancio Sociale emerged as a result of the initiatives undertaken by two innovative and proactive managers (see Contrafatto, 2014a) who acted as institutional entrepreneurs (Battilana et al., 2009) in designing and constructing a "fashionable" (Interviewee 4) and useful document of communication with stakeholders, in particular members. Although the centenary celebration provided the opportunity to implement an innovation, this event alone is not sufficient to explain how and why the Bilancio Sociale emerged. Hence, it is necessary to attend to the institutional and organizational conditions that influenced the decision-making about the first Bilancio Sociale to grasp a fuller understanding.

With regard to the institutional conditions, one factor appears to be relevant. At the end of the 1990s there was growing adoption (KPMG, 2005) of the first forms of SER practices by a few pioneer organisations in several sectors, including banking and finance. The growing interest in SER practices by other competing (and not) organisations spurred some form of mimetic mechanisms (see Scott, 2008) in the Bank. As observed by an interviewee who experienced this SER process, the CEO, who was quite sensitive to "what was going on in the business and market", had "several contacts with other companies' managers who had already begun to introduce these [social accounting] practices in their business and organisations. These contacts gave [him] a push towards this" (Interviewee 8). These findings chime with the results of other studies in the social and environmental accounting literature (e.g. Bebbington et al., 2009; Contrafatto, 2014a), which show how the initial adoption of social accounting practices is influenced by some form of mimicry of other, not necessarily competing, organisations.

In addition to the conditions of the wider institutional environment, it is necessary to attend to the specific organisational context. In the 1990s when the first Bilancio Sociale was developed, the Bank seemed to be increasingly oriented to, and driven by, a 'market and corporation based model'. 
As reported in the first Bilancio Sociale "the key competitive factor for [our] Bank is the links with the local territory; however, it has become more urgent to be active at a more national and international level, while remaining local. One of our main mottos is to buy global and sell local" (p. 25).

Even though the Bank was originally founded to provide micro-finance support to the local communities (artisans, farmers), during the 1980s the Bank went through a profound transformation. From the empirical evidence collected in the field, it appears that, over that time, the Bank gradually moved from the original 'community-focused and cooperative-based' orientation towards a more 'corporation-inspired and market-oriented' business model. This transformation was spurred by the former CEO, who brought into the organization a new marketoriented managerial attitude. According to Interviewee 5,

"The CEO was a strong supporter of a profit-oriented model of business and belonged to the generation of top managers who were hired [in the 1980/90s] to allow the rural banks to make a step forward [in the way of doing their business]".

From the perspective of the theory adopted in this paper, this transition from a 'community focused and cooperative-based' model towards a more 'corporation-inspired and market-oriented' model implied, and was signalled by, a change from the institutional logics related to the community order to those more related to the market and corporation orders (Thornton et al., 2012). The analysis of our empirical evidence shows that there was a change in the relevance of some of the categorical elements (e.g. source of legitimacy and basis of strategy) that characterise each of these institutional orders. With regard to the source of legitimacy, it has been observed that more emphasis was put on the "position of the Bank in the market" and the "economic performance" aspects, which are more related to the logics of corporation and market, rather than on "reciprocity and connection to the community", which are more related to community-based logics (see Table 1). For instance, during this time, attention was given to what competitors were doing, to comparative efficiency and the market position of the Bank (i.e. aspects which resonate with the market and corporation logics). As contended by Interviewee 1, who experienced these processes, at that time "we felt the need to look at the market and take into consideration the competition around us". The emphasis on these market and corporate-related aspects was also highlighted in the Bilancio Sociale published in 1999 and 2000. For instance, in the report published in 2000, explicit mention was made of the need to reconsider, in the light of efficiency, the Bank's decisions:

"The rapid evolution of the banking system has required a fundamental revision of the Bank's policies and initiatives. Over recent years there has been a significant growth in the number of branches in the local territory, which now has to be reconsidered in the light of the emerging needs of organizational efficiency and cost control” (Bilancio Sociale, 2000, p. 13).

Thus, our analysis shows that this gradual transition from community-based logics towards more market/corporation infused logics was relevant for the emergence of the first Bilancio Sociale. The contrasting effects that originated from this transition between these alternative logics provided the "opportunity" (Thornton at al., 2012) to introduce and justify some managerial innovation in the Bank's existing practices. In other words, the decision to introduce the first Bilancio Sociale, though it was created "for fun" (Interviewee 13), appears to be coherent with the Bank's organizational and institutional conditions. Consistently with other studies in the social accounting literature (see Bebbington et al., 2009; Contrafatto 2014a), this coherence with the institutional and organisational conditions helped the process of acceptance and adoption of the first Bilancio Sociale.

\subsection{The implementation of SER: from a fashionable toy to a key managerial tool}


The Bilancio Sociale, after its first appearance, increasingly received more consideration. As explained by Interviewee 13,

"At the beginning, the entire process was a bit hazy because this was novel for everyone. But after that, we gradually realized that this novel initiative was appreciated and that there was an interest in this document".

The case findings reveal that more structured and organized SER procedures were gradually implemented, including the way in which data and information to be included in the Social Reports were collected. In addition, more personnel were involved in the process of preparing Social Reports. After the first publications,

"the process was improved to involve more departments and staff. At the beginning, the departments involved in the Bilancio Sociale were not so many, but over the years there has been an increased engagement of people and offices" (Interviewee 8).

In particular, in 2002 a new person was hired as Head of Secretariat of the CEO. This person, who had formal responsibility for the production of the Social Reports, was specifically appointed for his experience and knowledge of the banking sector and the cooperative movement. Since his first appointment, and a few years later when he became the new CEO, he promoted changes to SER by modifying, for example, the layout and format of the Bilancio Sociale; the content and issues covered; and the process of reporting. As he explained himself,

"when I arrived in 2002 I started to ask for a new layout, which had a family look. The external appearance and format went together with the content. The goal was to make a product that was built, fostered and managed within the Bank" (Interviewee 5).

These changes to SER were emphasized in the Introduction to the Bilancio Sociale 2005 according to which "these [past] years have signalled important transformations in terms of forms and content. [...] But also in terms of the people who have been appointed, i.e. the new CEO, to relaunch the image [of SER] with a new focus being on members and community" (Bilancio Sociale, 2005, p.3). In terms of content and number of issues covered, the Social Reports published from 2002 onwards were gradually extended in length and number of issues covered. From our analysis of the published documents, we observe that the number of pages increased from 39.5 pages in 2002 to 126.5 in 2010 (see Appendix 1). More information was given about the initiatives (e.g. charitable donations and sponsorships) undertaken in favour of the members, employees and the community. In particular, the Social Reports were gradually enriched with stories about the members and a new story-telling approach was introduced. This approach, as it is argued by an interviewee, was "undertaken because it could make the Bilancio Sociale a more participative tool, which is able to communicate day by day what the Bank is doing for the community" (Interviewee 3).

The new CEO played a pivotal role in these SER-related transformations. In particular, his role could be interpreted as that of an enlightening institutional entrepreneur who championed these managerial changes. In particular, the CEO drew on his specialization, experience and knowledge of the CBs, which represent fundamental resources for institutional entrepreneurship (Thornton et al., 2012), to innovate the SER processes and documents.

With regard to the processes of SER, it was decided to establish and set up in 2005 a specific organisational unit, which was called the "Members Office". As explained by Interviewee 2, 
"this was an ex-novo department whose purpose was (and is) to manage relations with the members, to organize activities for members and for the community. Since then, the department has become the core unit to manage all issues related to the members and the community".

In particular, this new department had also responsibility for producing the Bilancio Sociale on a yearly basis (until 2011, as discussed below). These Social Reports were presented to the members during the Annual General Meeting "together with the financial statements, in order to build a better dialogue with the members" (Interviewee 13).

The Head of the Members Office, who is responsible for the coordination of the entire SER process, was specifically appointed because, in the words of an interviewee,

"he is the perfect person; he has great experience as a manager and he is also well-known in the local community. He is native of this area and went to nursery with many members of our community. He is very useful for the job that he does" (Interviewee 5).

Thus, as our analysis reveals, the Head of Members Office was appointed, because he was considered the right person to undertake this job. He had managerial experience of CBs but also a reputation within the local community to coordinate and manage a very sensitive department. Although he had little expertise and know-how of SER practices, this manager played an important role in the process of implementation and consolidation of SER. With the support of the new CEO and Deputy CEO, he was able to gradually transform the SER process and report towards more structured and organized forms. More specifically, he set up a Social Report Committee to help with managing and organizing the SER process. Overall, this process "involved twenty people, from the bank teller, to the financial account office, human resource and the finance office" (Interviewee 2).

In addition, it appears that the Head of the Members Office played an even more important role in dealing with, as discussed below, the 'mission re-balancing' and in 're-aligning the activities' that characterized the Bank over that period. Our analysis indicates that the manager possessed the necessary resources, particularly in terms of social reputation and community engagement (Battilana et al., 2009), to foster the organization throughout a phase of "re-communization", i.e. refocussing and emphasising community logics and values. The appointment of this manager as Head of the Members Office, we contend, signalled a gradual re-shift from the market-oriented and corporation-inspired logics to a community-focused and cooperative-based model. We observe that this re-shift was also enforced by the re-emergence of discourses and principles related to the religion logics, which, as observed above, had characterized the life of CBs since their beginning. For instance, this shift was characterised by a change in the relevance of some of the categorical elements of institutional orders, particularly the 'sources of identity', 'sources of legitimacy' and 'control mechanisms' (Thornton et al., 2012). With regard to the 'sources of identity', our analysis shows that more importance was given to the "social connection" with the values of the local community through the appointment of a person, as manager of the Members Office, who was a "well-known member of the local community" (Interviewee 5). With regard to the "sources of legitimacy", particular emphasis was given to the concepts of "faith" and "ethics", which reflects elements of the religion institutional order (see Table 1). Our content analysis shows that these concepts were increasingly used in the Social Reports that were published at that time. For example, reference was made to the values and principles of "ethics" (Bilancio Sociale, 2004), "faith and common good" (Bilancio Sociale, 2008) and "solidarity" (Bilancio Sociale, 2004, 2007, 2008). As reported in the Bilancio Sociale 2004,

"The values of Catholic thought are essential elements of [our] economic development [...]. Our purpose is solidarity, which represents moral and concrete aid for the members of our communities (pp. 1-3). 
Moreover, with regard to 'control mechanisms', more emphasis was given to making "visible the actions" (Thornton et al., 2012) which were carried out in favour of the local community and members by reporting the several philanthropic and community investment initiatives which were undertaken by the Bank. For instance, an increasing number of pages of the Bilancio Sociale (from 10 in the 1999 to 40 pages in the 2010) were dedicated to the disclosure of these initiatives. This new attitude was also emphasized by Interviewee 5,

"we are a rural bank and live here. Fundamentally, we are a territorial bank: this is our vocation. We need to disclose what we do not only in terms of [economic] numbers, but also [in terms] of social actions".

These changes in SER-related processes were influenced by some "events" that occurred in the wider institutional context, in particular those related to the Argentina default, which occurred in 2001/2002 and whose effects lasted for several years. As a result of these events, the overall banking and finance system was in uproar over its unethical behaviour. This general uproar also affected the Bank, which faced severe criticism for having invested in Argentinian bonds ${ }^{12}$. This posed major concerns, because, as contended by two interviewees, "that period was for our Bank the worst in terms of trust and reputation with our members" (Interviewee 7) because "we are not a normal Bank, we are different" (Interviewee 11). The need to regain trust and reputation by distinguishing the Bank from the commercial banks was seen as necessary. These differences from the commercial banks had been repeatedly emphasised by the interviewees,

"I do not want to say that we are saints and the other banks are the demons, but there are differences in the relationship with the people and in our activities' impact on the territory" (Interviewee 3, emphasis added).

Differentiation strategies were sought by the Bank as a way to highlight the differences and to compete with the other banks, in particular commercial banks ${ }^{13}$. For example, the Bank adopted the motto "our Bank is different" (Interviewee 11) ${ }^{14}$. It appears that this motto was used in the Bank to communicate this new attitude to re-embrace the original mission, i.e. to operate within a territory for enhancing the development of local communities. In this specific context, the "cool toy" (Interviewee 4) of the Bilancio Sociale was increasingly seen as a relevant managerial tool to "rebuild a dialogue with the members which had been ignored for a long time" (Interviewee 1). In particular, the Bilancio Sociale was gradually used as a managerial mechanism for, as explained by Interviewee 11, "demonstrating to our members that our mission [was] respected". From the theory adopted in this paper, thus, the Argentinian crisis represented a relevant "exogenous event" (Thornton et al., 2012) which challenged the Bank to reconsider their existing practices and to critically re-think what its real mission should be. It would appear that the Bank's way of operating was too distant from its mission and that there was the risk, in the words of an interviewee, of "having distorted what our mission was" (Interviewee 5) because of excessive focus on the market rather than on the community and cooperative aspects. Thus, the empirical evidence shows that at

\footnotetext{
12 The choice to invest in high-risk bonds such as Argentinian appears to be inconsistent with the values and principles of a CB. However, it may be plausible that this choice was made because of the orientation towards a more marketinspired management approach, which, as observed above, characterized the Bank's activities in the late 1990s.

${ }^{13}$ The Bank is located, as expressed by Interviewee 1, in the "plaza with most banks", i.e. in an area "with the highest density of banks". In such a competitive context, therefore, the adoption of specific differentiation strategies was seen necessary for gaining competitive advantage.

${ }^{14}$ This emphasis on "being different" was reported also in the Bilancio Sociale 2005, which emphasizes that "important differences between the cooperative and other banks exist. In contrast to other banks, the cooperative banks generate wealth that is distributed to the whole community through, for example, the support to local associations and producers" (p.3)
} 
that time the Bank experienced a form of mission-drift (Ebrahim et al., 2014; Mersland and Strøm 2010), i.e. a deviation from its social value-mission as a result of the initiatives that had been previously undertaken to embrace a more market-oriented and corporation-inspired business model. Interviewee 1 argues that at that time a need was felt to "return to [our] original mission, i.e. to provide benefits primarily to [our] members and local community".

This form of mission-rebalancing seemed to emerge out of the existence of two contradictory dominant institutional logics (i.e. the community vs market-corporation) that influenced the actions of the Bank. These contradictions provided the resources and opportunity for changing the managerial attitudes and practices of the organisation. Our analysis show that, it was in this specific context that the SER gradually became an important managerial element through which to deal with the mission re-balancing (Ebrahim et al., 2014). SER and related documents were used to reconstruct and re-shape more trustworthy relationships with the members, because, as contended by Interviewee 13, "there was an absolute need for our Bank to create a clearer and more transparent dialogue with our members".

Our analysis has revealed that the initiatives (e.g. the appointment of a new CEO; the creation of the Members Office and the appointment of new management; the structured implementation of SER), which were gradually implemented from 2002, appear to be aimed at re-balancing the mission of the Bank and the management focus more towards the members and local community. As a result of this managerial approach, a more explicit intention of the Bank to return back to its raison d'être emerged, i.e. to pursue the goals of providing financial/economic services to the families, farmers and in general its local community. As argued by Interviewee 1,

"the previous CEO and Deputy CEO gave a strong footprint to the corporate market, but [in this Bank] we have to pursue a more balanced equilibrium between the corporate and the retail markets".

In this process of re-orientation, which was influenced and driven by a gradual change from the market/corporation to the community logics, SER increasingly played a key role. Our analysis shows that SER represented a formal mechanism through which to communicate and account for this new organisational attitude and to better manage its relationships with the members. In other words, the implementation and structuring of SER appeared to be an important element for reconstructing new 'accountability mechanisms' (O'Dwyer and Unerman, 2008) with the primary stakeholders (i.e. members and the local community). In particular, SER was used in our case study for "making more visible", "understandable", and therefore "recognizable", the social initiatives, which were undertaken by the Bank as a result of its mission and activities re-balancing. By paraphrasing Ebrahim (2005, 2009), the SER was a key component of the process of "accountability", which was more oriented and focused on the public interests of the local community and members. From the perspective of Thornton et al., (2012), SER became an important categorical element of the community-infused logics, which influenced the activities of the Bank in this phase.

\subsection{The gradual de-structuring of SER}

After 2011 the SER practices were subjected to a gradual process of de-structuring that affected the nature (i.e. scope, content and format) and role of SER within the Bank. As mentioned before, destructuring indicates changes that affect the manifestations of SER, i.e. the reporting, policy and scope/content of report. From our analysis it appears that the SER, which emerged for "fun" (Interviewee 13) out of the initiatives of two visionary managers, became and remained prominent and well-structured in the Bank as long as there was the urgency to re-equilibrate the mission and to account for the initiatives that were undertaken by the Bank. 
Although SER was initially seen as a powerful 'accountability mechanism' (Ebrahim, 2005), some scepticism gradually emerged with regard to its actual effectiveness. In particular, questions were raised about whether SER and related documents were the "right tool[s]" (Interviewee 14) for re-constructing more transparent relationships with members and the community. Some interviewees expressed dismay that the Social Report "is not able to restore a link with the members and the community [...]. On the other hand, I am not sure members are able to understand it" (Interviewee 12). The SER and related documents, which emerged out of the implementation phase, were perceived to be, as put by an interviewee, too "sophisticated" and "overkill", and thus actually "ineffective" for the accountability purposes of the Bank (Interviewee 5). As argued by Interviewee 5, "members, who are more rustic (i.e. less sophisticated) stakeholders, do not always understand the differences between a Financial and a Social Report". In addition, the existing SER practices were criticized for not being able to create real engagement with the members and local community. From this perspective, the existing SER practices were seen as tools for one-way communication rather than for interaction and connection with stakeholders. In the words of Interviewee 11, the Social Report is like a "television, something that is communicating with me, but with which I am no longer communicating". Our empirical analysis indicates that SER gradually lost some of its appeal and relevance within the organisation. As a result of this, SER started to be de-structured in terms of content, format and processes.

With regard to content and format, the Social Reports published after 2011, were amended with the purpose of making them more readable and understandable; and they were drastically reduced in length. For example, the Bilancio Sociale 2013 and 2015 consisted only of six-page long leaflets full of pictures, graphs and tables with very little narrative.

An important role was played by the 'Working Group for the Bilancio Sociale' that started to operate from 2011 and gained relevance thereafter. The working group, which included the managers who were involved in the SER, was responsible for proposing improvements to the existing SER practices. From the perspective of the theory adopted in this paper, this group performed some form of collective institutional entrepreneurship (Battilana et al., 2009) because, through their active involvement, they were able to introduce changes in the existing organizational practices. In particular, as explained by Interviewee 3,

"we started to reflect on alternative formats. The idea was to adopt video, texts, images, music and [partially] numbers to effectively deliver [our] messages. The main rationale for this was that a few messages expressed in a concise way could potentially be more effective than long pages of report" (emphasis added).

If on the one hand these changes in format and style made the Social Reports more readable and accessible for the Bank's "rustic stakeholders", on the other hand they affected the nature and role of SER that gradually became more a communication tool to illustrate the Bank's socially responsible initiatives. In other words, these changes, we contend, signalled a first step towards the process of de-structuring SER and related documents, which increasingly became, in the words of an interviewee, a "beautiful book" (Interviewee 9) for showing, and possibly less for formally accounting for, the initiatives undertaken by the Bank. As explained by Interviewee 2,

"We employed mainly pictures and photos because the Presidents of the local associations, which we support with our charities activities, need to portray and see themselves in these activities and initiatives".

As mentioned before, the Social Report was presented and disseminated only during the Annual General Meeting in which the members were invited to take part. The Social Report was not the main focus of these meetings, which were mostly dedicated to the presentation of the financial and economic results of the Bank: 
"There is not the willingness to illustrate first the Social results and then the economic ones. [...] During the Annual Meetings, $90 \%$ of time is devoted to Financial Reports and, at the end only $5 \%$ is given to the Social Report" (Interviewee 2).

Changes were also introduced in the format used to present the Bilancio Sociale during the Annual General Meetings. In particular, a more visual and video based format has been recently adopted. As emphasized by Interviewee 3, over the last few years:

"the presentation of the Bilancio Sociale to the members [has been] performed in a more concise way, through some slides at the end of the Assembly General meeting; and the whole content of the Social Report has been summarized in a video".

In addition, changes also affected the procedures and policies followed to prepare the Social Reports, including the frequency of publication. Our analysis shows that starting from 2012 the Social Reports were prepared on a two-year basis rather than yearly as they had been until then. Moreover, since the constitution of the 'Members Office', which had been in charge of managing the entire SER process, no formal procedures or policies were actually implemented though these had been initially envisaged. As Interviewee 3 explains,

"[the Head of the Members Office] is responsible for the entire process of the Bilancio Sociale: the timing, the structure and the main draft of the Report. He informally contacts the people who are required to prepare the information via e-mail and then he collects all the materials; [he] is also responsible for the printing. He is the only contact person".

From the analysis of our empirical evidence, it emerges that from 2012 the process of SER started to be managed in a casual and quite un-formalized way, i.e. in a "craft artisan" way (Interviewee 2). Although policies and procedures had been initially proposed, these were not ultimately adopted nor implemented. There was a sort of 'backward process', whereby the managers decided to recede from the initial intention of policies and procedures formalization. As argued by Interviewee 13,

"we have decided not to impose rules. One of the things that should be avoided in a small rural bank is excessive bureaucratization. The Head of the Members Office has no rules and policies to strictly respect and follow".

It would appear that the choice of not adopting and implementing specialised SER-related policies and procedures was taken because these were considered ineffective and potentially damaging for the SER processes:

"this was something that we deliberately decided to do [...] because if you create highly formalized structures, practices and policies, these have a negative impact on the whole organization because they undermine responsibilities" (Interviewee 5).

The choice of not implementing formal policies and procedures for SER was motivated, as our interviews reveal, by a desire to reduce 'bureaucratization' in the Bank. If interpreted from the perspective of the theory adopted in this paper, this choice appeared to be coherent with the transformation towards more 'community-inspired' logics that occurred in the Bank over that period. The SER represented, in this sense, a key medium tool (Busco et al., 2017; Järvinen, 2016) that played an important role by mediating tensions and re-balancing the Bank's logics towards its initial mission. This transformation, for example, signalled a shift from "bureaucratization" towards "social forms of connection", which represent 'the sources of identity' (Table 1) of the 
'corporation' and 'community' institutional orders respectively (Thornton et al., 2012). On the other hand, however, the decision to not adopt formal policies and procedures gives further evidence of the gradual de-structuring of SER.

In summary, after 2011 the Bank undertook a profound rethinking about SER, which was subjected to a gradual process of de-structuring that affected the reporting, policy and content/format of reports. This was illustrated by the fact that in more recent years short and concise leaflets were produced instead of the conventional forms of Social Reports. On several occasions, the interviewees highlighted that the SER process is "home-made" (Interviewee 5) and is managed in a "household" (Interviewee 13) way. In other words, it appears that the SER was tailored and redesigned to fit with the organisational purposes of the Bank, i.e. the need to manage the accountability-based relationships with their members and local communities. From this perspective, therefore, the process of de-structuring seems to be part of this attempt at making SER something that "fits with" (Contrafatto, 2014a) the needs of the organisation. In the context of the Bank, which is a relatively small bank operating in a localised area, there was the need to communicate and account for the initiatives carried out in a simple and understandable way. Our analysis reveals that over this period there was a gradual shift from more formalized and structured forms of accountability towards more unstructured and home-made mechanisms, i.e. towards a form, by paraphrasing Walker and Llewelyn (2000), of "household accountability" that is more informal, visual and symbol-based. In particular, it is possible that this shift was influenced by a form of "transposition" (Thornton et al., 2012) in the 'Basis of Control' of the existing communityinspired institutional order (Table 1). As a result of this transposition, a categorical element of another institutional order (i.e. the 'Family') appeared to be transferred and blended with the community-inspired institutional logics, which were influencing the actions and initiatives undertaken in the Bank. In this specific context, the role and nature of SER changed. In particular, our analysis shows that SER became gradually a symbolic element of corporate communication, through which to show and visualize the initiatives undertaken by the Bank. SER still played a very important role, because, as put by an Interviewee, it was "something useful because it [was] a beautiful thing to show" (Interviewee 5).

\section{Conclusions}

This paper has examined SER evolution dynamics, i.e. how and why these evolution-related dynamics occurred over time. In particular, this paper offers a theoretically informed analysis of the processes and conditions under which SER emerged, was constructed and developed in an Italian cooperative bank. The analysis of the empirical evidence has unveiled three stages in the evolution of SER: i) the 'birth' whereby a new form of social reporting was introduced; ii) the 'development' through which SER was implemented and structured; and iii) the 'de-structuring' when the SER was gradually de-composed.

In the case study, SER appears to be "inconstant" and "multifunctional" in nature. Our analysis reveals that SER, even when it has been initiated and implemented, does not seem to be necessarily a permanent and long-standing structured practice. In other words, even when SER is not dismissed outright, it can be subtly and gradually de-structured and possibly downplayed. These results chime with Vinnari and Laine (2013) and Belal and Owen (2015), which showed that SER may be decomposed and may decline as result of several organizational and institutional factors such as, for example, the absence of public demands for wider transparency. Our research shows that this process of gradual de-structuring, which may occur in a relatively short period, was influenced by some type of institutionally-infused rationalities. In the Bank, these institutionally-based rationalities seemed to be organisation-focused and were based, similarly to that observed by Contrafatto (2014a), "on the idea of designing SER in such a way that [is] congruent with the organisational needs" (p. 429).

In particular, these institutionally-based rationalities represent, from the perspective of Thornton et al., (2012, 2017), institutional orders and related logics. These institutions and related logics 
played an important role to explain why and how SER was initiated, implemented and eventually de-structured in our case study. Over these phases, not only did SER evolve and modify but it also played multiple functions within the organisation.

The paper contributes to the existing literature in several ways. First, the paper provides a contribution to the social and environmental accounting literature, as it sheds light on some of the complexities related to decision-making about SER. Our analysis shows that the decision of introducing the first Bilancio Sociale, which was driven by the CEO and Deputy CEO who exerted some form of institutional entrepreneurship (Di Maggio, 1988), occurred in a context of profound organizational transformations. These transformations were characterized by a transition from 'community-focused and cooperative-based' logics towards a more 'corporation-inspired and market-oriented' model of organizing. The fragmentation and contradictions that originate from this ILs-related transition (Thornton et al., 2012), created the 'space' for managerial innovation (Busco et al., 2017). However, it was the 'centenary', in our case study, that represented the relevant organizational event (Battilana et al., 2009) that provided the "resources" and "opportunity" for the SER-related change to take place. In this sense, though the initiation of the Bilancio Sociale was something "intended" and "desired" (Battilana et al., 2009), this decision was not grounded on managerial and strategic practicalities, but it was the result of the senior managers' curiosity about something unique for a special occasion (i.e. the centenary). The first Bilancio Sociale appeared to be a cool accessory that was drafted almost accidentally and without much prior planning. These results add to the existing literature by highlighting that the decision to initiate SER may not be driven only by strategic considerations (Bebbington et al., 2009; Adams and McNicholas, 2007), but rather were influenced by the willingness to propose some 'innovation' for specific organizational events (e.g. the anniversary).

Second, the results of the implementation stage provide a main theoretical contribution to the institutional (logics) theory, as they provide empirical evidence to shed light on the mechanisms of institutional agency and change. Our analysis shows that, starting from the early 2000s, the SER was gradually structured to become a key managerial component in the Bank. Over this period, the perceived increasing competition, along with some critical events (e.g. the Argentinian crisis), contributed to the emergence of a renewed managerial attitude, focus and orientation, which were influenced by a re-equilibrium between, and towards, the institutional order (and related logics) of community versus the corporation-market. This re-equilibrium created the space and opportunity for changes in managerial practices. It was in this specific context that SER gained impetus and managerial/strategic relevance. An important role in this SER-change process was played by the new CEO and the Head of the 'Members Office', who acted as innovative institutional entrepreneurs. If on the one hand, as predicted by Thornton et al., (2012) and Seo and Creed (2002), the contradictions between institutions and related logics provide "opportunities" and "spaces" for institutional change, on the other hand these opportunities required the "active involvement" (Battilana et al., 2009) of some institutional entrepreneurs to be activated. In particular, this institutional entrepreneurship was spurred by specific institutional and organisational conditions (e.g. competition and disruptive events) which provided, in our case, the necessary resources (e.g. justification and authority) for proposing and introducing changes. Hence, our analysis reveals that institutional change occurred as a result of the favourable combination of these three different elements, i.e. the opportunities created by fragmented and contradictory logics; the resources provided by specific institutional and organisational conditions/events; and the active agency (Scott, 2008), whether strategy-motivated or not, exerted by institutional entrepreneurs. From this perspective, therefore, it is important to attend to this 'favourable interlinks' to grasp a fuller understanding of institutional change dynamics. However, our research does not explain 'how' and 'under what conditions' this favourable combination of institutional-change related elements occurs. More in-depth research should be conducted to explore, through comparative and longitudinal investigation, the dynamics and processes related to institutional dynamism and change (Quattrone, 2015). 
Finally, our paper provides a main contribution to understand the complex nature of accountability mechanisms by illuminating the multi-faced ways in which accountability can be enacted and the role of SER in these processes (see O'Dwyer and Unerman, 2007; 2008). Our analysis shows that the changes in SER appeared to be consistent with the changes in the accountability-related purposes of the organisation. When after 2011 it was perceived that a more "rustic" and "home-made" form of accountability was necessary, the nature and role of SER gradually changed. SER became something still important to deliver, though it was considerably more de-structured and less formally-organized than before. This de-structuring, though it may at first glance give rise to some perplexities, may be interpreted as a coherent consequence of the changes in the accountability-related needs and expectations of the Bank, i.e. a small and localised cooperative bank. It may be that for the Bank a formal, structured and hierarchical form of accountability, which privileges external oversight and control (O'Dwyer and Unerman, 2008), was not effective nor necessary, once a more balanced business approach had been achieved. It is possible that this de-structured and "home-made" SER (Contrafatto et al., 2015) was appropriate, and even more effective, to realize a form of "household accountability", which could be aimed at creating a privileged relationship (O’Dwyer and Unerman, 2007) with two main stakeholders: members and local communities. Our analysis shows that, as suggested by O'Dwyer and Unerman (2007, 2008), "alternative", and perhaps stronger, forms of accountability exist: accountability which is less distant, structured, formal and hierarchical and which is able to create spaces and opportunities for "encounters" (Contrafatto et al., 2015) between organisations and their stakeholders. More research is needed to explore in more detail the conditions under which these alternative forms of accountability and accounts emerge and the effects they may have in relation to sustainable organisational changes. 


\section{References}

Adams, C.A. and McNicholas P. (2007), "Making a difference: sustainability reporting, accountability and organisational change", Accounting, Auditing \& Accountability Journal, Vol. 20 No. 3, pp. 382-402.

Ahrens, T. and Chapman, C.S. (2006), "Doing qualitative field research in management accounting: Positioning data to contribute to theory", Accounting, Organizations and Society, Vol. 31, No. 8, pp. 819-84.

Almandoz, J. (2012), “Arriving at the starting line: The impact of community and financial logics on new banking ventures", Academy of Management Journal, Vol.55 No 6, pp. 1381-1406.

Battilana J, Leca B. and Boxenbaum E. (2009), "How actors change institutions: toward a theory of institutional entrepreneurship", Academy of Management Annals, Vol.3 No. 1, pp. 65- 107.

Battilana, J. and Dorado, S. (2010), "Building Sustainable Hybrid Organizations: The Case of Commercial Microfinance Organizations", Academy of Management Journal, Vol.53, pp. 1419-40.

Bebbington J., Higgings C. and Frame B. (2009), "Initiating sustainable development reporting: evidence from New Zealand", Accounting, Auditing and Accountability Journal, Vol. 22, No. 4, pp.588-625.

Belal, A., and D.L. Owen (2015), "The rise and fall of stand-alone social reporting in a multinational subsidiary in Bangladesh: A case study", Accounting, Auditing \& Accountability Journal, Vol. 28, No. 7, pp.1160-1192.

Boitier M. and Riviere A., (2013), "Freedom and Responsibility for French Universities: from global steering to local management", Accounting, Auditing \& Accountability Journal, Vol. 26, No. 4, pp. 616-649.

Bonfanti A. (2009), Le Banche di Credito Cooperativo. Un futuro che viene da lontano, Giuffrè Editore, Milano.

Broadbent, J., and Laughlin, R. (2003), "Control and Legitimation in Government Accountability Processes: The Private Finance Initiative in the UK", Critical Perspectives on Accounting, Vol.14 No 1-2, pp. 3-48.

Busco, C., Giovannoni, E. and Riccaboni, A. (2017), "Sustaining multiple logics within hybrid organisations: Accounting, mediation and the search for innovation", Accounting, Auditing \& Accountability Journal, Vol. 30 No.1, pp.191-216.

Contrafatto, M. (2014a), "The institutionalization of social and environmental reporting: an Italian narrative", Accounting, Organizations and Society, Vol. 39 No. 6, pp. 414-432.

Contrafatto, M (2014b), "Stewardship theory: approaches and perspectives", in Costa, E., Parker, L. and Andreaus, M. (Eds), Accountability and Social Accounting for Social and Non-profit Organizations, Advances in Public Interest Accounting, Emerald Group Publishing, Bradford, pp. 153-176.

Contrafatto, M. and Burns, J. (2013), "Social and environmental accounting, organisational change and management accounting: A processual view", Management Accounting Research, Vol. 24, No.4, pp. 349-365.

Contrafatto, M., Thomson, I. and Monk, E., (2015), "Peru, mountains and los niños: dialogic action, accounting and sustainable transformation", Critical Perspectives on Accounting, Vol. 33, No. 12, pp. 117-136.

Creswell, J. W. (1998). Qualitative inquiry and research design: Choosing among five traditions. Thousand Oaks, CA: SAGE Publications.

Damayanthi,S. and Gooneratne, T. (2017) "Institutional logics perspective in management control research: A review of extant literature and directions for future research", Journal of Accounting \& Organizational Change, Vol. 13 Issue: 4, pp.520-547.

Deegan C. (2002). Introduction- The legitimising effect of social and environmental disclosures $-\mathrm{a}$ theoretical foundation, Accounting, Auditing \& Accountability Journal, 15 (3): 282-311

Dees, J.G. (1998), "Enterprising nonprofits”, Harvard Business Review, Vol. 76 No. 1, pp. 55-66. 
Dey, C. (2007), "Social Accounting at Traidcraft plc: A struggle for the meaning of fair trade", Accounting, Auditing and Accountability Journal, Vol. 20, No. 3, pp.423-445.

DiMaggio, P. (1988) "Interest and Agency in Institutional Theory", In L. G. Zucker (ed.) Institutional Patterns and Organizations: Culture and Environment, pp. 3-21. Cambridge, MA: Ballinger.

Ebrahim, A. (2005), “Accountability Myopia: Losing Sight of Organizational Learning”, Nonprofit and Voluntary Sector Quarterly, Vol. 34 No. 1, pp. 56-87.

Ebrahim, A. (2009), "Placing the Normative Logics of Accountability in 'Thick' Perspective", American Behavioral Scientist, Vol. 52 No. 6, pp. 885-904.

Ebrahim, A., Battilana, J., and Mair, J. (2014), "The governance of social enterprises: Mission drift and accountability challenges in hybrid organizations", Research in Organizational Behavior, Vol.34, pp. 81-100.

Eisenhardt, K.M. (1989), 'Building theories from case study research', Academy of Management Review, Vol. 14, No. 4, pp. 532-550.

Ezzamel, M., Robson, K., and Stapleton, P. (2012), "The Logics of Budgeting: Theorization and Practice Variation in the Educational Field", Accounting, Organizations and Society, 37(5): 281-303.

Fiordelisi, F., and Mare, D.S. (2014). "Competition and financial stability in European cooperative banks". Journal of International Money and Finance, Vol.45, pp. 1-16

Fraser, M. (2012), "Fleshing out" an engagement with a social accounting technology", Accounting, Auditing \& Accountability Journal, Vol.25, pp. 508-534.

Georgakopoulos, G. and Thomson, I. (2008), "Social Reporting, Engagements, Controversies and Conflict in an Arena Context", Accounting Auditing \& Accountability Journal, Vol. 21 No.8, $1116-1143$.

Gray, R., Adams, C., and Owen, D. (2014). Accountability, Social Responsibility and Sustainability: Accounting for Society and the Environment. London: Pearson Education Limited.

Greenwood, R. Suddaby, R. and Hinings, C.R (2002) "Theorizing change: The role of professional associations in the transformation of institutional fields", Academy of Management Journal, Vol. 45, pp. 58-80.

Hardy, C., and Maguire, S. (2008) "Institutional Entrepreneurship". In R. Greenwood, C. Oliver, K. Sahlin-Andersson, and R. Suddaby (eds.) The SAGE Handbook of Organizational Institutionalism, pp. 198-217. Thousand Oaks, CA: Sage.

Holm, P. (1995) "The dynamics of institutionalisation: Transformation processes in Norwegian fisheries", Administrative Science Quarterly, Vol. 40, pp. 398-422.

Järvinen, J.T. (2016) "Role of management accounting in applying new institutional logics: A comparative case study in the non-profit sector", Accounting, Auditing \& Accountability Journal, Vol. 29 Issue: 5, pp.861-886

KPMG (2005). International survey of corporate responsibility reporting 2005. Univeriteit van Amsterdam

Krippendorff, K. (2004) Content Analysis. Thousand Oaks, CA: Sage.

Lander, M. W., Koene, B. A. S., and Linssen, S. N. (2013) "Committed to Professionalism: Organizational Responses of Mid-Tier Accounting Firms to Conflicting Institutional Logics", Accounting, Organizations and Society, Vol.38 No. 2, pp. 130-148.

Larrinaga-González, C. and Bebbington, J., (2001) "Environmental Accounting Practices Organisational Change or Institutional Appropriation", Critical Perspectives on Accounting, Vol.12 No.3, pp. 269-292.

Larrinaga-González, C. and Perez-Chamorro, V (2008), "Sustainability accounting and accountability in public water companies". Public Money and Management, Vol. 28 No. 26, pp.337-343 
Leonardi, A. (1982), Per una storia della cooperazione trentina. Volume I, La Federazione dei consorzi cooperativi dalle origini alla prima guerra mondiale (1895-1914), Franco Angeli, Milano.

Leonardi, A. (1998), "Il ruolo di Lorenzo Guetti nella scelta cooperativa del Trentino", in Leonardi A. (a cura di), Lorenzo Guetti un uomo per il Trentino, Trento: Temi, p. 179-208.

Mersland, R. and Strøm, R. Ø, (2010), Microfinance mission drift?, World Development, Vol. 38, No. 1, pp. 28-36.

Miles, MB. and Huberman, AM. (1994), Qualitative Data Analysis (2nd edition), Thousand Oaks, CA: Sage Publications.

Ocasio, W., Thornton, P.H \& M. Lounsbury (2017), "Advances to the Institutional Logics Perspective”. In: Greenwood, R.; Oliver, C.; Lawrence, T \& R., Meyer (Orgs.). The Sage Handbook of Organizational Institutionalism. 2nd. ed. Sage, p. 509-531.

O'Dwyer, B. (2002), Managerial perceptions of corporate social disclosure: An Irish story. Accounting, Auditing \& Accountability Journal, Vol. 15 Issue: 3, pp.406-436.

O'Dwyer, B. (2004), Qualitative Data Analysis: Illuminating a Process for Transforming a 'Messy' but 'Attractive' 'Nuisance'. In C. Humphrey, \& B. Lee (Eds.), The Real Life Guide to Accounting Research: 391-407. Oxford: Elsevier.

O'Dwyer, B. and Unerman, J. (2007), "From functional to social accountability: transforming the accountability relationship between funders and non-governmental development organisations", Accounting, Auditing \& Accountability Journal, Vol. 20 No. 3, pp. 446-71.

O'Dwyer, B. and Unerman, J. (2008), "The paradox of greater NGO accountability: A case study of Amnesty Ireland", Accounting, Organizations and Society, Vol. 33 No 7-8, pp. 801-824.

O'Dwyer, B. and Unerman J. (2016), "Fostering rigour in accounting for social sustainability", Accounting, Organizations and Society, Vol.49, pp.32-40.

Pache, A., \& Santos, F. (2010). When worlds collide: The internal dynamics of organizational responses to conflicting institutional demands. Academy of Management Review, 35(3), 455476.

Pache, A. C., and F. Santos (2013), "Inside the hybrid organization: Selective coupling as a response to competing institutional logics", Academy of Management Journal, Vol. 56 No. 4, pp. 972-1001.

Pesci, C. and Costa, E., (2014), "Content analysis of social and environmental reports of Italian Cooperative Banks: methodological issues", Social and Environmental Accountability Journal, Vol. 34 No.3, pp. 157-171.

Quattrone, P. (2015), "Governing social orders, unfolding rationality, and Jesuit accounting practices: A procedural approach to institutional logics", Administrative Science Quarterly, Vol. 60, No. 3, pp. 411-445.

Roberts, J. (1991), "The possibilities of accountability", Accounting, Organisations and Society, Vol. 16, No 4, pp. 355-368.

Scott, W. R., (2008), Institutions and Organizations: Ideas and Interests. Sage, Los Angeles.

Scott, W. R., Ruef, M., Mendel, P. and Caronna, C. (2000), Institutional Change and Health Care Organizations: From Professional Dominance to Managed Care, Chicago: University of Chicago Press.

Seo M.G. and Creed, W. (2002), "Institutional contradictions, praxis, and institutional change: a dialectical perspective", Academy of Management Review, Vol.27 No. 2, pp. 222-247.

Silverman, D. (2011). Qualitative Research, 3rd Ed. London: SAGE Publications, Ltd.

Sinclair, A. (1995), "The chameleon of accountability: Forms and discourses", Accounting, Organizations and Society, Vol. 20, No. 2, pp. 219-237.

Thornton, P.H. (2004). Markets from Culture: Institutional Logics and Organizational Decisions in Higher Education Publishing. Stanford, CA: Stanford University Press. 
Thornton, P.H. and Ocasio, W. (2008), "Institutional Logics". In: Greenwood, R.; Oliver, C.; Sahlin, K.; Suddaby, R. (Orgs.). The Sage Handbook of Organizational Institutionalism. 1. ed. Sage, p. 99-129.

Thornton, P.H., Ocasio, W. and Lounsbury, M. (2012). The institutional logics perspective. Oxford: Oxford University Press.

Tilling, M. V., and Tilt, C. A. (2010), "The edge of legitimacy: voluntary social and environmental reporting in Rothmans' 1956-1999 annual reports", Accounting, Auditing \& Accountability Journal, Vol. 23 No.1, pp. 55-81.

Unerman, J., (2000), "Methodological issues, reflection on quantification in corporate social reporting content analysis", Accounting Auditing and Accountability Journal, Vol.13 No.5, pp. 667-680.

Vinnari, E. \& Laine, M. (2013), "Just a passing fad? The diffusion and decline of environmental reporting in the Finnish water sector". Accounting, Auditing \& Accountability Journal, Vol.26 No. 7, pp. 1107-1134.

Walker, S.P and Llewellyn, S. (2000), “Accounting at home: some interdisciplinary perspectives", Accounting, Auditing \& Accountability Journal, Vol. 13, No. 4, pp.425-449. 
Table 1. An Interpretive Framework of the Institutional Logic Perspective*

\begin{tabular}{|c|c|c|c|c|c|c|c|}
\hline \multirow{2}{*}{$\begin{array}{c}\text { Y-axis: } \\
\text { Categories }\end{array}$} & \multicolumn{7}{|c|}{ X-axis: Institutional Orders } \\
\hline & FAMILY & COMMUNITY & RELIGION & $\begin{array}{c}\text { CORPORATI } \\
\text { ON }\end{array}$ & MARKET & PROFESSION & STATE \\
\hline Root metaphor & $\begin{array}{l}\text { Family as } \\
\text { firm }\end{array}$ & $\begin{array}{l}\text { Common } \\
\text { boundary }\end{array}$ & Temple as bank & $\begin{array}{c}\text { Corporation as } \\
\text { hierarchy }\end{array}$ & Transaction & $\begin{array}{c}\text { Profession as } \\
\text { relational } \\
\text { network }\end{array}$ & $\begin{array}{c}\text { State as } \\
\text { redistribution } \\
\text { mechanism }\end{array}$ \\
\hline $\begin{array}{ll}2 & \text { Sources of } \\
6 & \text { legitimacy } \\
6 & \end{array}$ & $\begin{array}{c}\text { Unconditional } \\
\text { loyalty }\end{array}$ & $\begin{array}{l}\text { Belief in trust \& } \\
\text { reciprocity }\end{array}$ & $\begin{array}{l}\text { Importance of } \\
\text { faith, ethics \& } \\
\text { sacredness }\end{array}$ & Market position & $\begin{array}{c}\text { Economic } \\
\text { performance } \\
\text { (e.g. share } \\
\text { prices) }\end{array}$ & $\begin{array}{l}\text { Personal } \\
\text { expertise }\end{array}$ & $\begin{array}{l}\text { Democratic } \\
\text { participation }\end{array}$ \\
\hline $\begin{array}{l}\text { Sources of } \\
\text { authority }\end{array}$ & $\begin{array}{l}\text { Patriarchal } \\
\text { domination }\end{array}$ & $\begin{array}{l}\text { Commitment in } \\
\text { community } \\
\text { values \& } \\
\text { ideology }\end{array}$ & $\begin{array}{l}\text { Priesthood } \\
\text { charisma }\end{array}$ & $\begin{array}{l}\text { Board of } \\
\text { directors }\end{array}$ & $\begin{array}{l}\text { Shareholder } \\
\text { activism }\end{array}$ & $\begin{array}{l}\text { Professional } \\
\text { association }\end{array}$ & $\begin{array}{l}\text { Bureaucratic } \\
\text { domination }\end{array}$ \\
\hline $\begin{array}{l}\text { Sources of } \\
\text { identity }\end{array}$ & $\begin{array}{l}\text { Family } \\
\text { reputation }\end{array}$ & $\begin{array}{l}\text { Emotional and } \\
\text { social } \\
\text { connection: } \\
\text { ego-satisfaction } \\
\text { \& reputation }\end{array}$ & $\begin{array}{l}\text { Association with } \\
\text { deities }\end{array}$ & $\begin{array}{c}\text { Bureaucratic } \\
\text { roles }\end{array}$ & Faceless & $\begin{array}{c}\text { Association } \\
\text { with quality of } \\
\text { craft }\end{array}$ & $\begin{array}{c}\text { Economic/soc } \\
\text { ial class }\end{array}$ \\
\hline 29 Basis of norms & $\begin{array}{l}\text { Membership } \\
\text { in household }\end{array}$ & $\begin{array}{c}\text { Group } \\
\text { membership }\end{array}$ & $\begin{array}{l}\text { Membership in } \\
\text { congregation }\end{array}$ & $\begin{array}{l}\text { Employment in } \\
\text { firm }\end{array}$ & Self-interest & $\begin{array}{l}\text { Membership in } \\
\text { association }\end{array}$ & Citizenship \\
\hline Basis of attention & $\begin{array}{l}\text { Status in } \\
\text { household }\end{array}$ & $\begin{array}{c}\text { Personal } \\
\text { investment in } \\
\text { groups }\end{array}$ & $\begin{array}{l}\text { Relation to } \\
\text { supernatural }\end{array}$ & $\begin{array}{l}\text { Status in } \\
\text { hierarchy }\end{array}$ & $\begin{array}{l}\text { Status in } \\
\text { market }\end{array}$ & $\begin{array}{l}\text { Status in } \\
\text { profession }\end{array}$ & $\begin{array}{l}\text { Status of } \\
\text { interest } \\
\text { groups }\end{array}$ \\
\hline $\begin{array}{l}36 \text { Basis of strategy } \\
38 \\
39 \\
40\end{array}$ & $\begin{array}{c}\text { Increase } \\
\text { family honor }\end{array}$ & $\begin{array}{l}\text { Increase status } \\
\& \text { honor of } \\
\text { members \& } \\
\text { practices }\end{array}$ & $\begin{array}{c}\text { Increase religious } \\
\text { symbolism of } \\
\text { events }\end{array}$ & $\begin{array}{l}\text { Increase size \& } \\
\text { diversification } \\
\text { of firm }\end{array}$ & $\begin{array}{c}\text { Increase } \\
\text { efficiency \& } \\
\text { profit }\end{array}$ & $\begin{array}{l}\text { Increase } \\
\text { personal } \\
\text { reputation }\end{array}$ & $\begin{array}{c}\text { Increase } \\
\text { community } \\
\text { good }\end{array}$ \\
\hline $\begin{array}{l}\text { Basis of control } \\
\text { 1) Control } \\
\text { Mechanisms }\end{array}$ & $\begin{array}{l}\text { Family } \\
\text { politics }\end{array}$ & $\begin{array}{l}\text { Visibility of } \\
\text { Actions }\end{array}$ & $\begin{array}{c}\text { Worship and } \\
\text { devotion }\end{array}$ & $\begin{array}{l}\text { Organisation } \\
\text { culture }\end{array}$ & $\begin{array}{l}\text { Industry } \\
\text { analysts }\end{array}$ & $\begin{array}{c}\text { Celebrity } \\
\text { professionals }\end{array}$ & $\begin{array}{c}\text { Backroom } \\
\text { politics }\end{array}$ \\
\hline $\begin{array}{l}\text { 2) Accountability } \\
\text { Forms** }\end{array}$ & $\begin{array}{l}\text { Household } \\
\text { Accountability } \\
\text { (Walker and } \\
\text { Llewelyn, 2000) }\end{array}$ & $\begin{array}{c}\text { Public Interest } \\
\text { Accountability } \\
\text { (Ebrahim 2009; } \\
\text { O’Dwyer and } \\
\text { Unerman, 2008) }\end{array}$ & $\begin{array}{c}\text { Stewardship- } \\
\text { infused forms } \\
\text { (Contrafatto, 2014b) }\end{array}$ & $\begin{array}{c}\text { Corporate } \\
\text { (social) } \\
\text { Accountability } \\
\text { (Gray et al., 2014) }\end{array}$ & $\begin{array}{c}\text { Financial } \\
\text { Accountability } \\
\text { (Roberts, 1991) }\end{array}$ & $\begin{array}{l}\text { Professional } \\
\text { Accountability } \\
\text { (Sinclair, 1995) }\end{array}$ & $\begin{array}{l}\text { Government } \\
\text { Accountability } \\
\text { (Broadbent and } \\
\text { Laughlin, 2003) }\end{array}$ \\
\hline $\begin{array}{l}\text { Economic } \\
\text { Systems }\end{array}$ & $\begin{array}{c}\text { Family } \\
\text { capitalism }\end{array}$ & $\begin{array}{l}\text { Cooperative } \\
\text { capitalism }\end{array}$ & $\begin{array}{l}\text { Occidental } \\
\text { capitalism }\end{array}$ & $\begin{array}{l}\text { Managerial } \\
\text { Capitalism }\end{array}$ & $\begin{array}{c}\text { Market } \\
\text { capitalism }\end{array}$ & $\begin{array}{l}\text { Personal } \\
\text { capitalism }\end{array}$ & $\begin{array}{c}\text { Welfare } \\
\text { capitalism }\end{array}$ \\
\hline
\end{tabular}

Modified from Thornton et al., (2012, p. 73).

* In the table we have highlighted in the grey shaded sections the institutional orders and logics which are relevant for the empirical analysis. In addition, the proposed integrations and/or modifications have been highlighted within the bold black line.

** The 'Accountability Forms' row has been added (using italics) to the original matrix to refer to the different forms of accountability for each of the identified institutional orders. 
Table 2. Interviews: duration and length

\begin{tabular}{|c|c|c|c|c|}
\hline Interview & Accessibility & Duration (h: min: sec) & $\begin{array}{c}\text { Number of } \\
\text { pages }\end{array}$ & $\begin{array}{c}\text { Number of } \\
\text { words }\end{array}$ \\
\hline 1 & Private & $01: 14: 11$ & 17 & 5,722 \\
\hline 2 & Private & $01: 34: 51$ & 30 & 10,114 \\
\hline 3 & Private & $01: 15: 54$ & 26 & 8,799 \\
\hline 4 & Private & $01: 03: 27$ & 23 & 7,739 \\
\hline 5 & Private & $01: 30: 45$ & 26 & 9,580 \\
\hline 6 & Private & $00: 49: 08$ & 16 & 4,991 \\
\hline 7 & Private & $00: 55: 03$ & 18 & 4,866 \\
\hline 8 & Private & $01: 10: 08$ & 26 & 9,137 \\
\hline 9 & Private & $00: 33: 00$ & 10 & 3,206 \\
\hline 10 & Private & $00: 45: 36$ & 12 & 3,931 \\
\hline 11 & Private & $00: 38: 38$ & 10 & 4,793 \\
\hline 12 & Private & $00: 43: 58$ & 9 & 4,551 \\
\hline 13 & Private & $01: 08: 49$ & 10 & 5,182 \\
\hline 14 & Private & $00: 40: 50$ & 8 & 3,781 \\
\hline Total & & $\mathbf{1 4 : 0 4 : 1 8}$ & $\mathbf{2 4 1}$ & $\mathbf{8 6 , 3 9 2}$ \\
\hline
\end{tabular}


Table 3. Data-reduction process*

\begin{tabular}{|c|c|c|c|}
\hline \multicolumn{2}{|c|}{$\begin{array}{l}\text { Data Reduction Process: } \\
\text { Phases and Rounds }\end{array}$} & \multirow{2}{*}{$\begin{array}{c}\text { Initial number of codes } \\
151\end{array}$} & \multirow{2}{*}{$\begin{array}{c}\text { Final number of codes } \\
130\end{array}$} \\
\hline 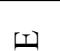 & 1 & & \\
\hline$\sum$ & 2 & 130 & 113 \\
\hline$a$ & 3 & 113 & 90 \\
\hline$\tilde{\approx}$ & 4 & 90 & 79 \\
\hline $\bar{I}$ & 5 & 79 & 71 \\
\hline \multirow{3}{*}{ 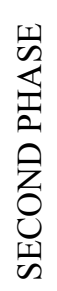 } & 6 & 71 & 48 \\
\hline & 7 & & 29 \\
\hline & 8 & 29 & 22 \\
\hline
\end{tabular}

* Data reduction involved two phases. The first included five rounds which reduced the 151 initial codes down to 71 final codes (see second and third column). The second phase, which included 3 different rounds, generated 22 final codes. These codes were grouped in six primary themes (i.e. 'core codes'): a) context (four codes); b) CSR (four codes); c) effects (two codes); d) motivations (two codes); e) SER processes (seven codes); and f) SER logics (three codes). 


\section{Figure 1: The processes and conditions related to SH}

PHASE 1end of 1990s until 2001

The birth of SER: the emergence of a new practice

FYSTITUTIONAÍ

AND 1 - The role of CEO and Deputy CEO as OKGANISATIONAL institutional entrepreneurs

CONDITIONS I-The centenary as a "salient endogenous 14 ONDIONS I event"

15

16

17

I\&STITUTIONA'L Shift towards market-infused and

\section{LOGICS} 20 DYNAMICS

21

22

23

24

25

I - Mimeticmechanisms

SER-

- First Bilancio Sociale in 1999

RELATED $\quad$ - Two people (CEO and Deputy CEO)

ROCESSES , involved in drafting SER

AND

(

corporation-based logics

CONTENT

- Basic format with limited information

SER used as a "fashionable" and "cool"

managerial toy

UNTAB BII

FORMS

\section{PHASE 2: from 2002 untu011}

\section{The implementation of} SER:

\section{manageriai structuration}

- Argentina default

- Global economic/ financial meltdown

- Perception ofa mission drift

- Changein the organisationalstructure:new CEO; set up of: a) the "MembersOffice",b) Working Group onthe Bilancio Sociale

- Weakening of the market/corporation logics

- Re-equilibration towards

community-infused logics and

cooperative-based business model

- 20 people involved in the SER processes

- Head of the CEO secretariatresponsible for

SER

- The "MembersOffice"Departmentin charge

for SER

- SER supportedby CEO and DeputyCEO

- Enriched contentent: SERas a Tüxury booklët

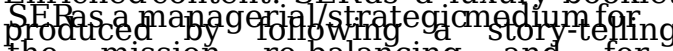
thporoacission re-balancing and for constructing closer accountability mechanism

- Public Interest Accountability/Stewardship -infused form

\section{PHASE 3: from2012 onwards}

The gradual de-structuring of SER

- Consequences of the financial crisis (Credit crunch)

- Focus on retail versuscorporate

- Re-shift to, and predominance of, community-based logics

- Transpositionof elements of some form of family-inspiredlogics

The previous structure has been maintained

The 'Working Group on the Bilancio Sociale' gained relevance for proposing changes to SER

- No implementation of the SER-policies nor of formal procedures

Symthetic structure with a as symbollc ameans for nymperafe parfersund atpotenth the main stakeholders: community and members. ! 
Appendix 1. Content analysis of the social reports from 1999 to 2015 by number of pages per themes.

\begin{tabular}{|c|c|c|c|c|c|c|c|c|c|c|c|c|c|c|c|}
\hline & \multicolumn{3}{|c|}{ PHASE 1} & \multicolumn{10}{|c|}{ PHASE 2} & \multicolumn{2}{|c|}{ PHASE 3} \\
\hline SER FEATURES & 1999 & 2000 & 2001 & 2002 & 2003 & 2004 & 2005 & 2006 & 2007 & 2008 & 2009 & 2010 & 2011 & 2013 & 2015 \\
\hline Format & \multicolumn{3}{|c|}{$\begin{array}{c}\text { Basic format and content: mission, } \\
\text { organisational structure and } \\
\text { philanthropic donations }\end{array}$} & \multicolumn{10}{|c|}{ Enriched content and format } & \multicolumn{2}{|c|}{$\begin{array}{c}\text { Format and structure: } \\
\text { Drastic drop in pages and } \\
\text { content }\end{array}$} \\
\hline Main content & \multicolumn{3}{|c|}{$\begin{array}{l}\text { Strong use of images to portray } \\
\text { employees, members and } \\
\text { customers }\end{array}$} & \multicolumn{10}{|c|}{$\begin{array}{l}\text { - More attention to language and terminology } \\
\text { - Story-telling approach }\end{array}$} & \multicolumn{2}{|c|}{$\begin{array}{l}\text { Folding images and } \\
\text { concise video used to } \\
\text { present the Bilancio } \\
\text { Sociale during the } \\
\text { General Assembly } \\
\end{array}$} \\
\hline Page Length & \multicolumn{3}{|c|}{ From 33.5 to 29.5} & \multicolumn{10}{|c|}{ From 39.5 to 122} & \multicolumn{2}{|c|}{6} \\
\hline CONTENTS & 1999 & 2000 & 2001 & 2002 & 2003 & 2004 & 2005 & 2006 & 2007 & 2008 & 2009 & 2010 & 2011 & 2013 & 2015 \\
\hline $\begin{array}{c}\text { Cover letter of the President } \\
\text { and/or CEO }\end{array}$ & 1 & 1 & 1 & 2 & 2 & 1 & 1 & 1 & 1 & 1 & 1 & 1 & 2 & 1 & 1 \\
\hline Methodological notes & 0 & 0 & 0 & 0 & 0 & 4 & 0 & 0 & 0 & 0 & 2 & 4 & 4 & 0 & 0 \\
\hline Mission, Identity and Values & 3.5 & 5 & 2 & 6 & 3.5 & 9.5 & 1 & 2 & 6 & 6 & 2 & 3 & 12 & 0 & 0 \\
\hline $\begin{array}{c}\text { Value added and economic } \\
\text { sustainability }\end{array}$ & 0 & 0 & 1 & 2 & 2 & 2 & 6 & 4 & 3 & 7 & 6 & 6 & 4 & 0.5 & 0.5 \\
\hline Members & 2 & 3 & 5.5 & 4.5 & 7 & 5.5 & 7 & 4 & 4 & 8 & 10 & 12 & 10 & 2 & 1.5 \\
\hline Philantropic initiatives & 10 & 9 & 6 & 9 & 6 & 10 & 19 & 32 & 20 & 31.5 & 36 & 40 & 10 & 0.5 & 0 \\
\hline Local community and people & 0 & 0 & 0 & 0 & 0 & 0 & 2 & 2 & 0 & 3.5 & 9 & 11 & 30 & 0.5 & 1.5 \\
\hline Customers & 0.5 & 2 & 1 & 1.5 & 3.5 & 3 & 6 & 0.5 & 8.5 & 5.5 & 9 & 11 & 12 & 0.5 & 0.5 \\
\hline Corporate governance & 11 & 9 & 8 & 7 & 4 & 5.5 & 6 & 8 & 4.5 & 6 & 4 & 4.5 & 2 & 0 & 0 \\
\hline Accountability & 0 & 0 & 0 & 1 & 0 & 1 & 2 & 0 & 2 & 3 & 0 & 0 & 0 & 0 & 0 \\
\hline Emplyoee & 3 & 2 & 2 & 1 & 3 & 3 & 6 & 8 & 8 & 16 & 17 & 15 & 14 & 0.5 & 0.5 \\
\hline Suppliers & 0.5 & 1 & 1 & 0.5 & 0 & 0 & 0 & 0 & 0 & 0 & 1 & 2 & 4 & 0.5 & 0.5 \\
\hline Continuous improvement & 0 & 0 & 0 & 0 & 0 & 0 & 0 & 0 & 0 & 0 & 2 & 0 & 4 & 0 & 0 \\
\hline Audit & 0 & 0 & 0 & 0 & 0 & 0 & 0 & 0 & 0 & 0 & 0 & 1 & 0 & 0 & 0 \\
\hline Feed-back for improvement & 0 & 0 & 1 & 1 & 1 & 1 & 1 & 1 & 1 & 1 & 1 & 1 & 0 & 0 & 0 \\
\hline Other issues & 2 & 0 & 1 & 4 & 3.5 & 3.5 & 0 & 2 & 4 & 0 & 9 & 15 & 14 & 0 & 0 \\
\hline Total number of pages & 33.5 & 32 & 29.5 & 39.5 & 35.5 & 49 & 57 & 64.5 & 62 & 88.5 & 109 & 126.5 & 122 & 6 & 6 \\
\hline
\end{tabular}


